\title{
Turizm İşletmelerinde İnsan Kaynakları Yönetimi İşlevi Olarak İnsan Kaynakları Planlaması ve Sorunlar Üzerine Bir Değerlendirme
}

\author{
Elbeyi PELİT ${ }^{1}$ ve Ahmet ÇETİN ${ }^{2}$
}

\section{Öz}

Günümüzde istihdam yaratıcı sektörlerin başında gelen hizmetler sektörü içinde turizm işletmeleri en önemli yeri oluşturmaktadır. Dünyanın her alanda yaşadığı makineleşme ve dijitalleşme üretimde emek faktörünün nicel olarak azalmasına sebep olmuştur. Ancak turizm işletmeleri belirli ölçüde bu otomasyondan etkilenmiş olsa da, hala insan faktörünün hizmet üretiminde en önemli unsur olduğu işletmelerdir. Müşteri memnuniyeti ve sadakatinin çalışan performansıyla doğrudan ilişki içinde olduğu turizm işletmelerinde insan kaynağı planlaması bu işletmelerin verimliliği için hayati önem taşımaktadır. İnsan kaynakları yönetiminin temelini oluşturan insan kaynakları planlaması, bütün bir insan kaynakları yönetim sürecinin başlangıcını da oluşturmaktadır. Bu yüzden planlamanın hatasız yapılması bütün bir sürecin sağlıklı işlemesini de sağlayacaktır. Bu çalışma turizm işletmelerinde insan kaynakları planlaması, insan kaynakları birimlerinin rolü ve planlamada ortaya çıkan hatalar ve bu hatalara çözüm önerileri getirmek amacıyla gerçekleştirilmiştir. Çalışmada, ulaşılan kaynaklar doküman incelemesi yöntemiyle taranmıştır. Ayrıca araştırmacıların sektördeki bireysel deneyim ve gözlemleri ile elde ettikleri sonuçlar literatürden elde edilen veriler ile birleştirilerek turizm işletmelerinde insan kaynakları planlaması ile ilgili ortaya çıkan sorunlar belirlenmeye çalışılmış ve bu sorunlara bazı çözüm önerileri getirilmiştir.

Anabtar Kelimeler: İnsan Kaynakları Planlaması, Turizm İşletmeleri, İnsan Kaynakları Planlama Sorunları

\section{An Investigation on Human Resource Planning as A Human Resource Management Function and Its' Problems in Tourism Business}

\begin{abstract}
Today, tourism enterprises constitute the most important place in the services sector, which is one of the leading sectors of employment creation. The mechanization and digitization in the world has led to a quantitative decrease in every field of labor factor in production. Although tourism enterprises are affected by this automation at a certain level, still the most important factor in production is human factor. Human resource planning in tourism establishments, where customer satisfaction and loyalty are directly related to employee performance, is vital for the efficiency of these enterprises. Human resources planning, which forms the basis of human resources management, constitutes the beginning of an entire human resources management process. Therefore, the planning of the whole process will ensure a healthy process. This study was carried out for the purpose of human resources planning in tourism enterprises, the role of human resources units and issues in planning and solutions to these issues. In the study, the sources were investigated by document analysis method. In addition, the results obtained from the individual experience and observations of the researchers in the sector are combined with the data obtained from the literature and the problems arising in the human resources planning in tourism enterprises have been tried to be determined and some solutions to these problems have been offered.
\end{abstract}

Keywords: Human Resource Planning, Tourism Enterprises, Human Resource Planning Issues

\section{Atıf İçin / Please Cite As:}

Pelit, E. ve Çetin, A. (2020). Turizm işletmelerinde insan kaynakları yönetimi işlevi olarak insan kaynakları planlaması ve sorunlar üzerine bir değerlendirme. Manas Sosyal Arastırmalar Dergisi, 9(2), 1268-1287.

Geliş Tarihi / Received Date: 29.03.2019

Kabul Tarihi / Accepted Date: 19.06.2019

\footnotetext{
${ }^{1}$ Prof. Dr. - Afyon Kocatepe Üniversitesi Turizm Fakültesi, elbeyipelit@aku.edu.tr ORCID: 0000-0002-6418-801X

2 Öğr. Gör. - Pamukkale Üniversitesi Denizli Sosyal Bilimler MYO, cetina@pau.edu.tr ORCID: 0000-0002-0753-8175
} 


\section{Giriş}

İşletmeler pazar paylarını, satışlarını ve karlarını artırmak için sürekli bir rekabet içerisinde yaşamlarını sürdürmektedir. Böyle bir ortamda başarll olabilmek için işletmeler sürekli maliyetleri düşürerek, ürün ve süreçleri yenileyerek, kaliteyi, üretkenliği ve pazara giriş hızlarını arttırarak performanslarını iyileştirmeye çalışır (Çalışkan, 2010, s. 101). Kurumsal ve stratejik yönetim gibi, insan kaynakları yönetimi de organizasyonun sürekliliği ve etkinliğinde önemli rol oynamaktadır. İnsan kaynakları yönetimi organizasyonun pazarlama, üretim ve satış gibi kurumsal işlevlerini etkin bir şekilde yerine getirebilmesi için çalışanlar ile ilgili kritik kararların alınmasında sistematik insan kaynakları planlamasını uygulayarak bu rolü yerine getirmektedir (Cania, 2014, s. 373-374).

İşletmeler dinamik birimlerden oluşan dinamik yapılardır. Bu yapılar içerisinde daima değişim ve gelişmeler, beklenen ya da beklenmedik durumlar yaşanabilir. Emeklilik, ölüm, iş kazaları gibi sebeplerle boşalan pozisyonlara personel bulmak, iş gücü devri, işletmenin genişleme planları, teknolojik değişimler ve gelişmeler ve ihtiyaçların değerlendirilmesi yani mevcut durum analizi işletmelerde insan kaynakları planlamasını gerekli kılan durumlardır (Kumar, 2011, s. 40-41). Ortaya çıkabilecek böylesi durumlar ya da stratejik planlar içerisinde gerçekleștirilen insan kaynakları planlama faaliyetleri gibi bütün planlama faaliyetleri daima bir süreci gerektirir. $\mathrm{Bu}$ sürecin aşamalarını, bilgilerin toplanması, analiz ve değerlendirme, geleceğe ilişkin tahmin ve sonuçların uygulanması oluşturmaktadır (Saruhan ve Yıldız, 2012: 251). Bu aşamaların her birinin kendi içinde çeşitli uygulamalar barındırdığı insan kaynakları planlama faaliyetleri, işletmelerin işgücü israfını ya da kıtlığını önleme ve ihtiyaçlarını belirleme konusunda işletmeler için vazgeçilmez bir öneme sahiptir (Reilly, 1996, s. 16-17). Ayrıca işletmelerde stratejik planların gerçekleştirebilmesi için insan kaynakları planlamasının da dâhil edilmesi gereklidir.

Turizm işletmeleri hizmetler sektörü içinde yer alan ve sanayi devriminden sonra hızla makineleşen üretim sistemi içerisinde hala emeğin en önemli üretim faktörü olduğu işletmeler arasında yer alır. Turizm sektöründe yer alan işletmeler arasında rekabet son derece yüksektir (Lew ve McKercher, 2006). Bu yüksek rekabet ortamında başarılı olabilmek için serbest piyasa ekonomisi içerisindeki işletmelerin diğerlerinden farklılaşması gerekmektedir (Martin vd. 2016, s. 31). Çünkü turist sayılarında büyük artışlar yaşanmasına rağmen taleplerin her geçen gün değişmesi ve ülkeler ve destinasyonlar arasında büyük benzerliklerin olması pazar içerisinde yer alan turistlerin çekimini ve memnuniyetini güçleştirmektedir. Müşteri memnuniyetinin üretilen hizmete (Sonne, 1999), üretilen hizmetinde ağırlıklı olarak emeğe dayalı olduğu turizm işletmelerinde hizmet kalitesinin artırılması ve müşteri memnuniyetinin sağlanması kaliteli bir insan kaynağına sahip olmakla doğru orantılıdır (Pelit ve Güçer, 2006, s. 159). Bu yüzden emeğin yönetilmesi büyük önem kazanmaktadır.

Dünya turizm örgütü, turizmin emek yoğun bir sektör olarak birçok insana istihdam sağladığını ancak minimum düzeyde bile mesleki yeterlilik ve yeteneğe sahip personel istihdamında sorun yaşandığını belirtmektedir. Bunun gerekçeleri arasında iş ve çalışma şartlarının personel beklentilerini karşılamamasını göstermekte bu nedenle insanların daha iyi iş fırsatları bulduğunda işten ayrıldığını ifade etmektedir (UNWTO, 2018). Turizm sektörü emek yoğun yapısı ve işgören devir oranının yüksekliği (Tuna; 2007; Ünlüönen ve Şahin, 2011, s. 18) sebebiyle insan kaynakları birimlerinin önem kazandığı sektörlerin başında gelmektedir. Özellikle stratejik insan kaynakları planlamasının işletmenin gelecek hedeflerini gerçekleştirmedeki yeri göz önüne alındığında bu önem ortaya çıkmaktadır. İnsan kaynakları yönetimi, planlama işlevi özelinde turizm işletmelerinin incelenmesi bu açıdan önemli görülmektedir. Bu çalışmada literatür taraması ile elde edilen veriler yardımıyla turizm işletmelerindeki insan kaynakları planlamasına ilişskin uygulamalar ve karşılaşılan sorunlar ortaya konularak bu süreçte insan kaynakları yönetimi biriminin rolüne değinilmiş ve konuya yönelik ilgili taraflara öneriler getirilmiştir.

\section{İnsan Kaynakları Yönetimi İşlevi Olarak İnsan Kaynakları Planlaması ve Turizm İşletmeleri Açısından Önemi}

Yönetimin temel fonksiyonlarından olan planlama, organizasyonların amaçlarına ulaşmak için araç ve imkânların seçimi veya belirlenmesi olarak tanımlanabilir (Ünsalan ve Şimşeker, 2011, s. 146). Planlama bir yerden başlaması ve belirli bir amaç için tamamlanması gereken bir süreci ifade eder. Yöneticilerin doğru kararlar alabilmesini sağlayan bilgileri toplamayı içerir. Elde edilen bilgiler hedeflere ulaşmak için de gereklidir. Planlama her faaliyette olduğu gibi insan kaynakları yönetiminde de son derece önemli ve belirleyici bir süreçtir (Demir ve Çavuş, 2010, s. 3). İnsan kaynakları biriminin işlevlerinden biri olan insan 
kaynakları planlaması esas itibariyle bir işletmenin insan kaynağ1 ihtiyacının tahmini ve ihtiyacının giderilmesi için faaliyetlerin basamaklandırılması anlamına gelmektedir (Pelit, 2015, s. 83).

İnsan kaynakları planlaması, gelecekte insan kaynağına ilişkin yapılması gerekenleri belirleyerek ortaya çıkabilecek değişimlere karşı politika ve stratejiler oluşturabilmek amacıyla yapılır. Bir örgütün işgücü talebini tahmin etmeye çalıştı̆̆1 ve bu talebi karşılanacağı arzın büyüklügünü, niteliğini ve kaynaklarını değerlendiren bir süreç olan (Reilly, 1996, s. 14) insan kaynakları planlamasının temel işlevi insan kaynağ1 talebiyle iç ve diş personel arzının uyumlaştırılması olarak ifade edilebilir (İbicioğlu, 2006, s. 1). İnsan Kaynakları planlaması uzun vade de işletmenin insan kaynağı ihtiyacını ve temin yöntemini belirleme sürecidir (DeCenzo ve Robbins, 2010). Ayrıca mevcut işgücü seviyesinin belirlenmesi ve ihtiyacın tespitinin yanında personelden faydalanma ve işgücü geliştirme işlemleri de planlama faaliyetleri kapsamında gerçekleştirilir (Keklik, 2007, s. 20). Bu sebeple işletme stratejilerinin oluşturulmasında insan kaynakları planlaması hayati bir rol oynar.

İnsan kaynakları planlaması iki düzeyde ele alınabilir. Birincisi insan kaynakları planlamasını örgüt boyutunda ele alan, örgüt içindeki çalışanların bugünkü durumunu ve geleceğe ilişkin ortaya çıkması beklenen değişikliği ele alan yaklaşımdır. İkincisi ise insan kaynakları planlamasını daha geniş ölçekte ele alan makro yaklaşımdır. Bu yaklaşımda ise, bir ülkenin iş gücü nitelik ve nicelik olarak ele alınarak incelenir (Kozak, 2012, s. 57). Kumar (2011, s. 37), ise insan kaynakları planlamasının farklı seviyeler ve farklı amaçlarla yapılabildiğini ulusal planlamacıların ulusal düzeyde bir plan gerçekleştirirken firma stratejistlerinin birim düzeyinde planlamalar gerçekleştirdiğini ifade etmektedir. Buna bağlı olarak ta planlama seviyelerini ulusal, sektörel, iş kolu (alt sektör), birim ve departmanlar seviyesinde olmak üzere beş farklı düzeyde ele almaktadır.

İnsan kaynakları planlamasını stratejik ve operasyonel olarak ele alan yaklaşımlara göre ise; stratejik insan kaynakları planlaması, stratejik insan kaynakları yönetimi çerçevesinde ortaya çıkan bir yaklaşımdır (Björkman ve Xiucheng, 2002). Stratejik insan kaynakları planlaması, organizasyonun belli bir döneme ait personel ihtiyaçlarının, belirlenen hedeflere ulaşabilmek için gerekli olan kalite düzeyinde sağlanmasını hedefler (Arslan, 2012, s. 91). Başarıyı yakalamak için işletmelerin hedeflerini ve bu hedefleri gerçekleştirmeyi sağlayacak insan kaynağını belirlemeleri gerekmektedir (Özer, 2015, s. 70). Bu süreç geleceğe dönük bir bakış açısı ile uzun vadeli gerçekleştirilmelidir. İşletmenin uzun dönemde başarıya ulaşabilmesi için gerekli hedefler ve stratejiler, bunları yürütebilecek nitelik, motivasyon ve yeteneğe sahip çalşanlar ile mümkündür. Bu yüzden stratejik insan kaynakları planlaması, işletme stratejisi doğrultusunda doğru zamanda, doğru kişilerin, doğru işlerde konuşlandırılması sürecidir (Sabuncuoğlu, 2000, s. 28; Arslan, 2012, s. 91; Torrington vd., 2017, s. 92). Bu yaklaşım daha çok işletmelerin uzun vadeli hedeflerinin gerçekleşmesine yönelik bir tutum oluştururken, operasyonel insan kaynakları planlaması ise kısa vadede gerekli işgücü ihtiyacının belirlenmesinde kullanılan bir yaklaşımdır (Boella ve Turner, 2013, s. 198).

Bir işletme içinde yer alan bütün çalışanlar o işletmenin insan kaynağını oluşturmaktadır. İnsan kaynakları yönetimi, işletmenin amaçlarına ulaşabilmesi için, var olan çalışanları en doğru ve etkin şekilde kullanarak verimliliği artırıcı bir görev üstlenmektedir. İşletmeler mal ve hizmetleri uygun yöntemleri kullanarak minimum maliyetle üretebilmek için verimliliği daima ön plana alırlar (Yüksel, 2000, s. 1). İşletmelerde verimlilik dinamik bir kavramdır ve ölçü parametresi zaman ve birim olarak ele alınır. Turizm işletmelerinde ise verimliliğin ölçülmesi oldukça zordur. Bunun temel sebebi turizm işletmelerinde, özellikle konaklama işletmelerinde çalışan her birey doğrudan müşteri ile birebir ilişki içerisindedir ve geliri de gideri de yaratan çalışanlardır. Bu yüzden turizm işletmelerinde işgücüne etki eden uygulamaların düzenlenmesi ve iyileştirilmesi işletme verimliliğine etki etmektedir (Kayınova, 2014). İşgücünü etkileyen uygulamalar işletmede yönetimin aldığı kararlar doğrultusunda yürütülmektedir. Bu kararlar işletme içinde yönetimin, gerekli araştırmalar ve planlamalar yapılmadan ve gerekli bilgiler olmadan alabileceği kararlar değildir. $\mathrm{Bu}$ bilgiler ise işletme içerisinde insan kaynakları birimlerinin elde ettiği ve veri tabanlarında depoladığ1 verilerden elde edilecek bilgilerdir (Calp, 2016, s. 542). İnsan kaynaklanı yönetimi bu verileri işletme içerisinde birden fazla fonksiyonu kullanarak toplamaktadır. Bu fonksiyonların yerine getirilmesi ise bir anlamda insan kaynakları planlama faaliyetleri ile başlamaktadır.

İnsan kaynakları planlaması, işletmenin insan kaynakları ihtiyaçlarına temel planlama süreçlerinin uygulanmasını içermektedir. Planların başarılı olabilmesi, işletmenin uzun dönemli planlarına ve faaliyet planlarına uygun olmasına bağılıdır. İşletmenin uzun vadeli planları işletmenin başarısı için çeşitli faktörleri bir araya getirmeye çalışır ve işletmenin pazardaki başarısına odaklanmıştır (Björkman ve Xiucheng, 2002; 


\section{PELIT ve ÇETIN}

Turizm İşletmelerinde İnsan Kaynakları Yönetimi İşlevi Olarak İnsan Kaynakları Planlaması ve Sorunlar Üzerine Bir Değerlendirme

Tonus, 2013). Günümüzde işletme stratejik planları içerisine daha fazla dâhil edilmeye başlanan insan kaynakları ile işletme stratejik planları arasında ciddi bir ilişki vardır. Stratejik planlar ile insan kaynakları planlarını bütünleştirmek işletme amaçlarına ulaşmak için gereklidir (Briggs ve Keogh, 1999, s. 447). İşletmelerin sürekli değişim içerisinde olan çevre koşullarına hızlı tepki verebilmesini sağlayan stratejik planlama, üst yönetimin kapsamlı örgütsel amaç ve hedefleri belirleme ve onları gerçekleştirme sürecidir (Jackson ve Schuler, 1990). Üst yönetim, insan kaynakları faaliyetlerinin stratejik hedeflerle ilişkilendirilerek bu hedeflere ulaşmada katkı sağlamasını bekler (Bingöl, 2016, s. 170). İşletmeye göre farklılık gösterebilecek işletme stratejilerine göre uygulanabilecek insan kaynakları planlamalarına ilişkin uygulanabilecek yöntemler şekil 1'de verilmiştir.

İşletmenin hedefleri doğrultusunda ihtiyaç duyduğu insan kaynağı belirlenerek, seçme, yerleștirme ve eğitim gibi faaliyetler ile ihtiyaç giderilir. İnsan kaynakları planlamasının işletme genel planlarıyla uyumlu olması gelecekteki işe alım ihtiyaçlarını değerlendirmek, eğitim programlarının oluşturulmasını kolaylaştırmak, terfi ve kariyer geliştirme politikalarını iyileştirmek ve değişen gereksinimlerin karşılanması için esnek bir işgücü sağlarken personel maliyetlerini azaltmaya da yardımcı olur (Deniz ve Ünal, 2007).

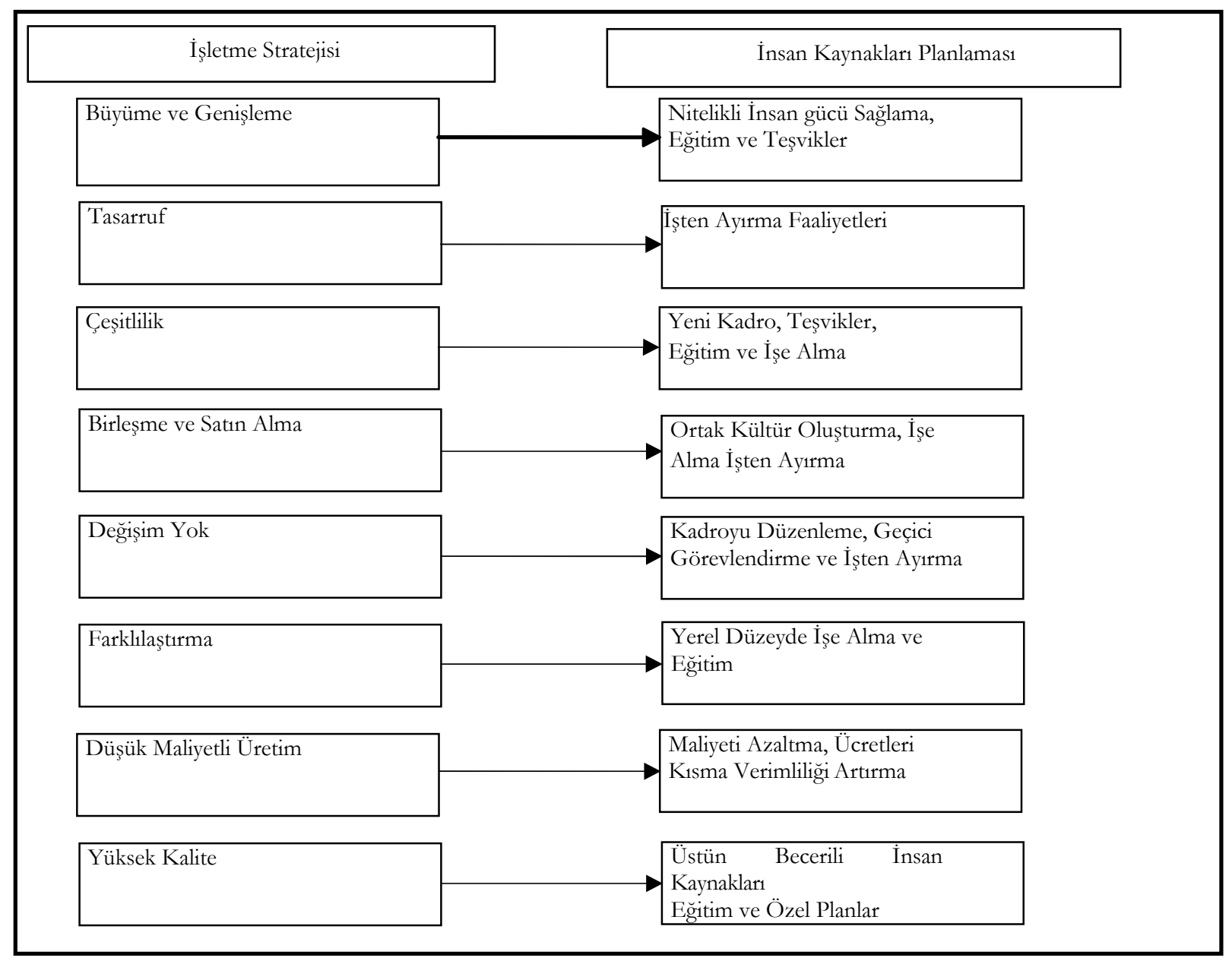

Şekil 1. İsletme Stratejileri ve İnsan Kaynakelar Planlaması

Kaynak: Anthony, W. P., Perrewe, P. L. ve Kacmar, K. M. (1996). Strategic human resource management. New York: Dryden Press.

İnsan kaynakları planlaması insan kaynakları fonksiyonları içerisinde diğer fonksiyonlarında yerine getirilmesinde asli rol oynayan bir fonksiyondur. İnsan kaynakları yönetimi içinde diğer fonksiyonlarla ilişkisi ve etkisi Şekil 2'de gösterilmiştir. 


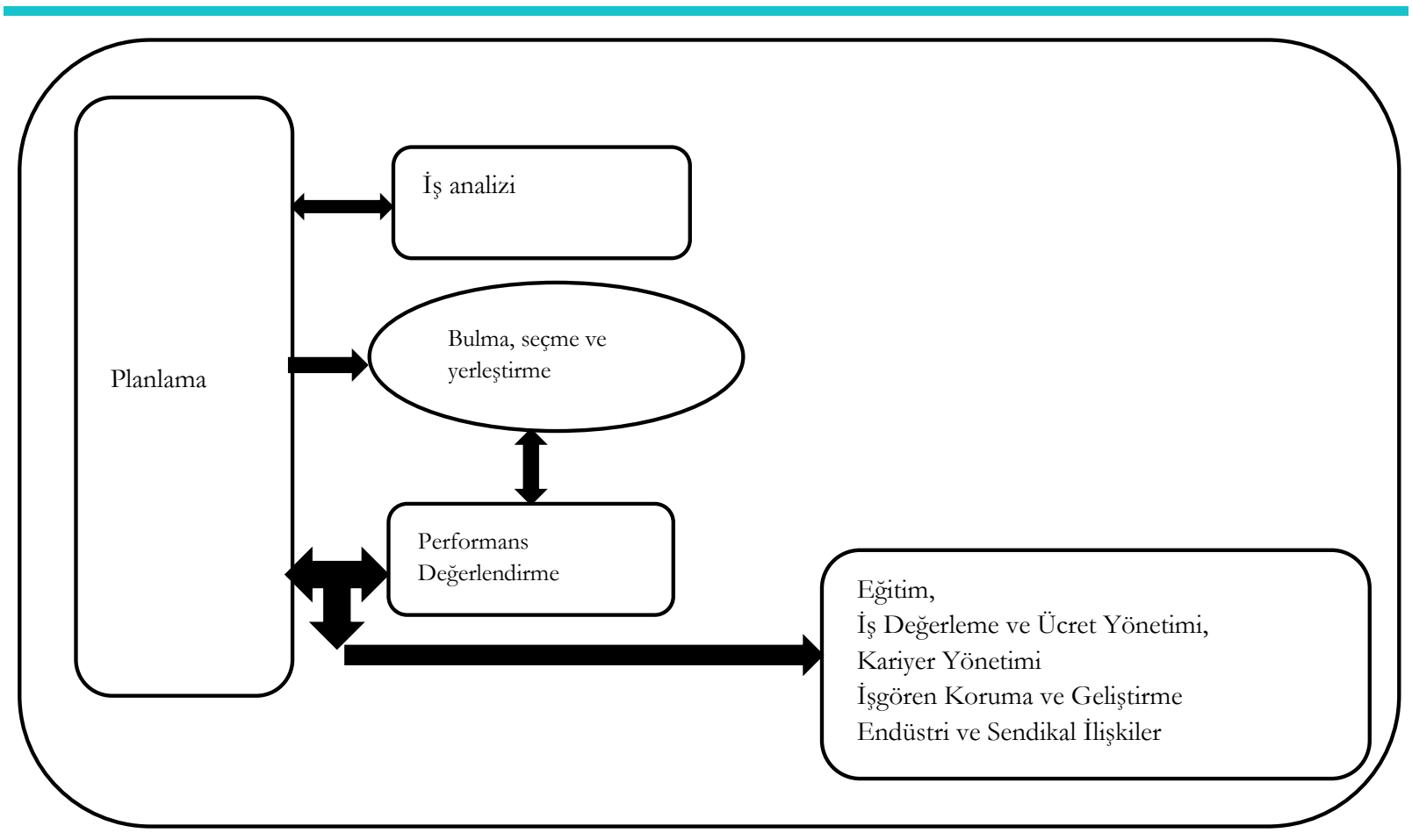

Şekil 2. Planlamann İnsan Kaynaklar Yönetimi İ̧̧indeki Yeri

Kaynak: Yazarlar tarafindan oluşturulmuştur

İşletmede insan kaynakları yönetimine ilişkin bütün faaliyetler insan kaynakları planlamasına bağlı olarak başlamalı yürütülmelidir. İşletme stratejileri ile uyumlu, insan kaynakları yönetimi stratejileri çerçevesinde gerçekleştirilen iş analizlerinden elde edilen veriler planlamanın ilk girdilerini oluşturmaktadır. İşletmenin ihtiyaç duyduğu personel ihtiyacının belirlenmesi için gerekli işlemler işgücü planlanması sürecinde gerçekleştirilerek, arz kaynaklarının tespiti yapılır. Eğer iç kaynaklar kullanılacak ise bununla ilgili performans değerleme ve işe uygunluğu değerlendirmek, eğitimleri organize etmek, kariyer planlanı ve ücret planlamalarını yapmak gerekir. İç kaynaklar yeterli değilse, bulma, seçme ve işe alma işlemlerinin gerçekleştirilmesi, oryantasyon ve eğitim gibi süreçlerin işletilmesi ve belirli bir süre sonra performans değerlendirmelerin gerçekleştirilerek alınan personelin yeterliliği ölçülmeli, gerekirse eğitimler artırılmalı ya da yeni personel bulma yoluna gidilmelidir. Bingöl'e (2016) göre işe alma, gelecekte ihtiyaç duyulan zaman ve yerde, belirli sayı ve nitelikte personel sağlanarak işletme faaliyetleri sorunsuz yürütülebilmesi gibi gerçek bir amaca dayandırılmalıdır. Böylece planlama faaliyetinde başarı sağlanması ya da boşalacak kadrolar için her yönden hazır personelin bulundurulmasındaki başarı (Palmer ve Winters, 1992, s. 34), aynı zamanda insan kaynakları yönetiminin bütün fonksiyonlarını etkin bir biçimde yerine getirmesine de yardımcı olacaktır (Bingöl, 2016).

İşletmenin stratejik planlarını gerçekleştirebilmesi bu planlara insan kaynakları planlamasının dâhil edilmesiyle mümkün olmaktadır. İnsan kaynağı planlaması bu yüzden tek başına düşünülemez ve Şekil 3'de belirtildiği şekilde işletme içindeki ve çevresindeki çeşitli unsurlarla etkileşim içindedir (Mathis ve Jackson, 2008). 


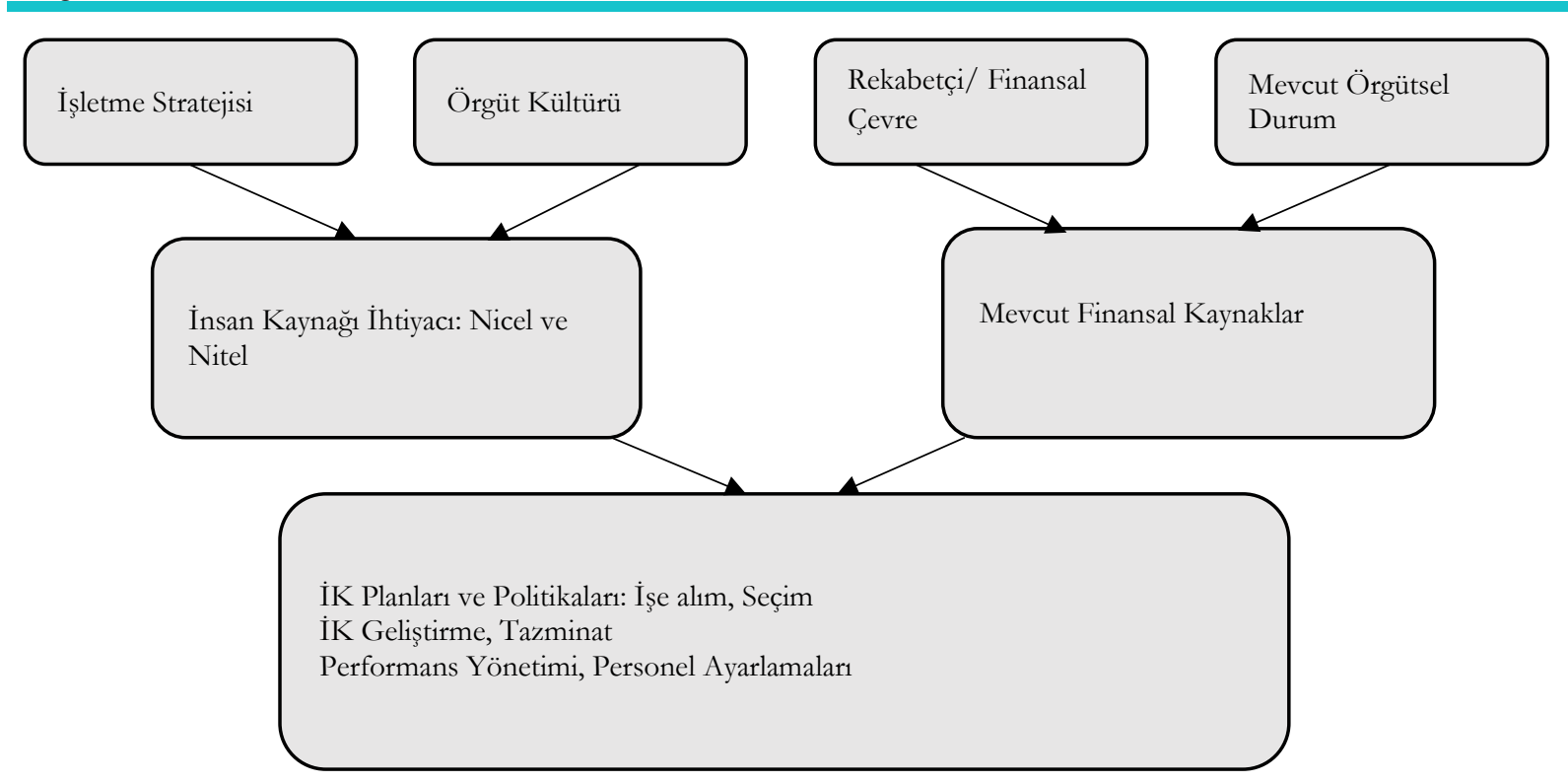

Şekil 3. Insan Kaynaklar Planlamasinda Etki Eden Faktörler

Kaynak: Mathis, R. L. ve Jackson, J. H. (2008). Human resource management (12 th Edition). Mason: Thomson.

Şekil 3, bir kurumun geliştireceği insan kaynakları planlarını nihai olarak belirleyen değişkenler arasındaki ilişkiyi göstermektedir. Görüldüğü gibi işletmenin iş stratejisi insan kaynakları alanındaki strateji ve faaliyetleri etkilemektedir (Martin vd., 2016). Örneğin bir otel işletmesinin stratejik hedeflerinden temel iki tanesi küresel bir geniş görüşlülük oluşturmak ve hizmet kalitesini yükseltmektir. Bu iki hedefin yerine getirilmesinde insan kaynakları iç pazar ve dış pazar operasyonlar için işe alım, tazminat, sosyal haklar vb. uygulamaları yerine getirerek işletmeye destek sağlamayı planlamaktadır. Ancak hizmet kalitesinin artırılmasının tamamen yetişmiş ve yetenekli personele bağlı olması (Becker ve Huselid, 1998) ve bu personelin teminin zor olması insan kaynakları planlamasına işletmenin hedefleri doğrultusunda personelin sağlanması için eğitim kurs ve seminerleri gibi uygulamaları da eklemelerini gerektirecektir. Bu şekilde insan kaynakları planlarının kurumsal stratejik planları desteklemesi ile otelin stratejik hedeflerine ulaşması sağlanacaktır.

Etkin bir insan kaynakları planlaması, işletmenin içindeki ve dışındaki gelişmeleri de içeren ve eğitim ve gelissim ihtiyaçlarını da kapsayan bir yapıya sahip olmalıdır (Yılmaz, 2008, s. 42). Buradan hareketle insan kaynakları planlamasının iki temel amacı olduğu görülmektedir. Bunlardan birincisi uygun değer düzeyinde eleman istihdam etmek ve ikincisi ise çalş̧anlardan azami şekilde istifade etmek (Bingöl, 2016, s. 172). Bu amaçları benzer şekilde ele alan Kumar (2011, s. 36) ise; insan kaynağının yeterli düzeyde tedarik edilmesi, insan kaynağının uygun kalitede olması ve insan kaynağının etkin kullanımı olarak üçe ayırmakta ve insan kaynakları faaliyetleri içerisinde planlamanın önemini bu konulara dayandırmaktadır. Genel olarak bakıldığında insan kaynakları planlaması işletmenin eksik ya da fazla personelle çalışmasını önleyen, çevresel değişimlere işletmenin uyum sağlamasında etkili olacak personelle ilgili faaliyetleri yönlendiren bir işlevdir (Yüksel, 2000, s. 68). İnsan kaynakları planlamasının amaçlarını pek çok araştırmacı benzer şekilde belirtmektedir. Barutçugil, (2004, s. 247) bu amaçları; "İnsan kaynağı ihtiyacına yönelik uzun ve kısa dönemli tahminler yapmak, çalışanları örgüte bağlayarak verimlerini arttırmak için ihtiyaçlarını karşılamak, insan kaynaklarına yapılan yatırımların geri dönüşümünü sağlamak, insan kaynaklarına ilisskin ihtiyaçlarla örgütün bütün olarak faaliyetleri arasında bağlantı kurmak, örgütün istihdam firsatlarını yakalamasını sağlamak, örgütte zaman içinde meydana gelen teknolojik değişim düzeyine göre oluşan çalışan fazlalığını öngörerek önceden gerekli önlemleri almak ve etkin bir insan kaynakları planlaması ile örgüt yönetiminin denetim yükünü azaltmak" olarak özetlemiştir. İnsan kaynakları planlaması yukarıda genel amaçları belirtilerek açıklanmaya çalışıldığı üzere, doğru zaman ve doğru yerde en ekonomik insan kaynağını sağlayabilecek faaliyetleri gerçekleştirme sürecini ifade etmektedir.

İnsan kaynağına yatırım günümüzde işletmelerin stratejik bir yaklaşım olarak benimsedikleri önemli konulardan biridir (Anca-Ioana, 2013, s. 1521). İnsan kaynağının her işletme için önemli olduğu kabul edilmekle birlikte, turizm işletmeleri için ayrı bir öneme sahiptir. Turizm işletmeleri çalışan ve müşteri arasında yoğun bir ilişkinin olduğu, işletme fonksiyonlarının yerine getirilmesinde çalşsanların en önemli 
rolü üstlendiği işletmelerdir (Angelo, 1998, s. 403). Bu yüzden çalışan performans1 işletme performansıyla doğru orantılı olarak değişebilmektedir.

İnsan kaynakları planlaması örgüt içi ve örgüt dışı değişkenlere ilişkin tahminlere dayalı geleceğe ilişkin çalısmaları ele alması bakımından önemlidir (Kozak, 2012). Turizm işletmelerinde örgüt içi değişkenler, emekli olma, işten ayrılma, sezonluk istihdam ve terfi gibi değişkenlerdir. Örgüt dış1 değişkenler ise, sektördeki talep esnekliğinin yüksek olması, eğitim düzeyindeki değişimler, sektörde meydana gelen yenilikler, toplumun mesleğe bakış açısı, rekabet şartlarındaki değişimler gibi değişkenler oluşturmaktadır. Özellikle talep esnekliğinin yüksek olduğu turizm sektöründe, bahsedilen bu değişkenlere ilaveten turist gönderen ülkelerdeki gelişmeleri, bu ülkelerdeki tur operatörlerini, bu ülkelerle olan siyasi ilişkilerin gelişimini vb. pek çok konuyu da göz önünde bulundurarak planlama yapmayı gerektirmektedir. Tahminlerin iyi yapılabilmesi hem örgüt hem de toplum açısından insan kaynağının en uygun kullanımına imkân sağlayacağı için planlama çok önem kazanmaktadır (Yüksel, 2000, s. 69).

Çağdaş yaklaşımlarda insan kaynakları planlaması, sadece personel sayılarıyla ilişkili değildir. Sayısal planlamalar yanında işletmenin sahip olduğu bilgi, beceri ve kalite (Dolgun, 2007, s. 33) gibi nitel unsurların geliştirilmesi ve örgütte kültürün oluşturulması, değisştirilmesi ve devamıyla ilgili bir kavramdır. Özellikle çalışan performansının işletme verimliliğine etkisi düşünüldüğünde turizm işletmelerinde müşteri memnuniyetini sağlamaya yönelik bir kültürün oluşturulması ve benimsenmesi oldukça önemlidir.

Turizm işletmeleri açısından insan kaynakları planlamasını belki de en önemli hale getiren ise, Türkiye gibi turizmin ülke ekonomisi için oldukça önemli olduğu ülkelerde sadece işletme devamlllı̆̆1 değil ülke kalkınmasının da göz önünde bulundurularak, rekabeti komşunuzla değil ülke sınırları dışında bulunan diğer işletmelerle yapmanın gereğinden kaynaklanmaktadır. Bu bakış açısı nitelikli işgücünü zorunlu hale getirmektedir. Dolayısıyla işletmelerin "personel lazım olduğunda nasıl olsa buluruz" mantı̆̆ıla değil stratejik planlama mantığıyla hareket etmeleri gerekir. İhtiyaç duyulan ve gelecekte ortaya çıkabilecek ihtiyaçlar belirlenerek insan kaynakları personel seçimi kariyer planlaması ve diğer aktiviteleri yerine getirmeli (Keklik, 2007, s. 22), insan kaynağı temin yolları, kaynakları ve zamanları belirlenerek doğru zaman da doğru kişiler seçilmelidir.

\section{Turizm İşletmelerinde İnsan Kaynakları Planlama Sürecinde İnsan Kaynakları Biriminin Rolü}

İnsanlar fizyolojik yapılarının karmaşıklı̆ğ kadar, hatta daha fazla ruh dünyası karmaşık canlılardır. Dolayısıyla insan kaynakları yöneticisi olarak, insanlarla ve insana ait işlerle uğraşmakta karmaşık ve zor bir iştir. Bunun nedeni sadece kurumsal kurallar, politikalar ve prosedürler ile uğraşmayıp, aynı zamanda farklı tipte kişilikler, ihtiyaçlar ve krizlerle de uğraşmak zorunda olmasıdır (Muoki, 2011, s. 3). Aynı zamanda insan kaynakları yöneticileri işletme için stratejik öneme sahip çeşitli görevleri de yerine getirmektedir. Bunlardan en önemlilerinden biride insan kaynakları planlamasıdır. Aslında işletmelerin insan kaynağı planlamasında her birim yöneticisi sorumluluk altındadır. Birim yöneticileri performans değerleme, planlama, atama gibi insan kaynakları fonksiyonlarının kendi birimleri ile entegrasyonundan sorumludur. İnsan kaynakları yönetici ve uzmanlarının bu noktada görevi araç, bilgi, eğitim ve destek sağlayarak yöneticilerin bu sorumluluklarını yerine getirmelerine yardımcı olmaktır (Cascio ve Aguinis, 2014, s. 253). Ancak insan kaynakları biriminin sorumlulukları yalnızca bundan ibaret değildir. İşletmeler geleceğe ilişskin belirsizlikleri en aza indirmek için planlama yapmaktadır. Hiçbir işletme hiçbir kaynağa sonsuz ölçüde sahip değildir. Sahip olduğu kaynakları iyi yönetmek ve olabileceği kaynakları öngörerek geleceğe bir ölçüde şekil vermek ve belirsizliği azaltmak zorundadır. İnsan kaynakları planlama süreci ve aşamaları şekil 4'de gösterilmiştir.

İşletmeler çevre analizlerini yaparken, stratejik amaçlarına ulaşmasına etki edebilecek dış çevre içerisindeki firsat ve tehditler ile içerideki güçlü ve zayıf yönleri belirleyerek, işletmenin işgücü piyasasındaki şimdiki ve gelecekteki eğilimlerin göz önüne alınmasına olanak sağlar. Ayrıca işletmenin elinde bulunan kaynaklarının, belirlediği amaçlara ulaşmasındaki yeterliliğini ölçme amacı da taşır (Arslan, 2012, s. 94). İnsan kaynakları planlamas1 süreci esas olarak insan kaynakları talebinin tahmin edilmesi, insan kaynakları arzının belirlenmesi ve bu arz ve talebin karşılaştırılmasını içerir.

İnsan kaynakları talebi tahmin edilirken gerçek, yedek, ek ve yeni olmak üzere dört farklı şekilde personel ihtiyacı tanımlanabilir (Tonus, 2013, s. 38). Bu ihtiyaçların belirlenmesinde iş analizi, personel devir hızı, devamsızlık oranı ve dış çevreyle ilgili bilgiler kullanılabilir. (Ağaoğlu, 1992; Dallı, 1998; Kozak, 2012). 


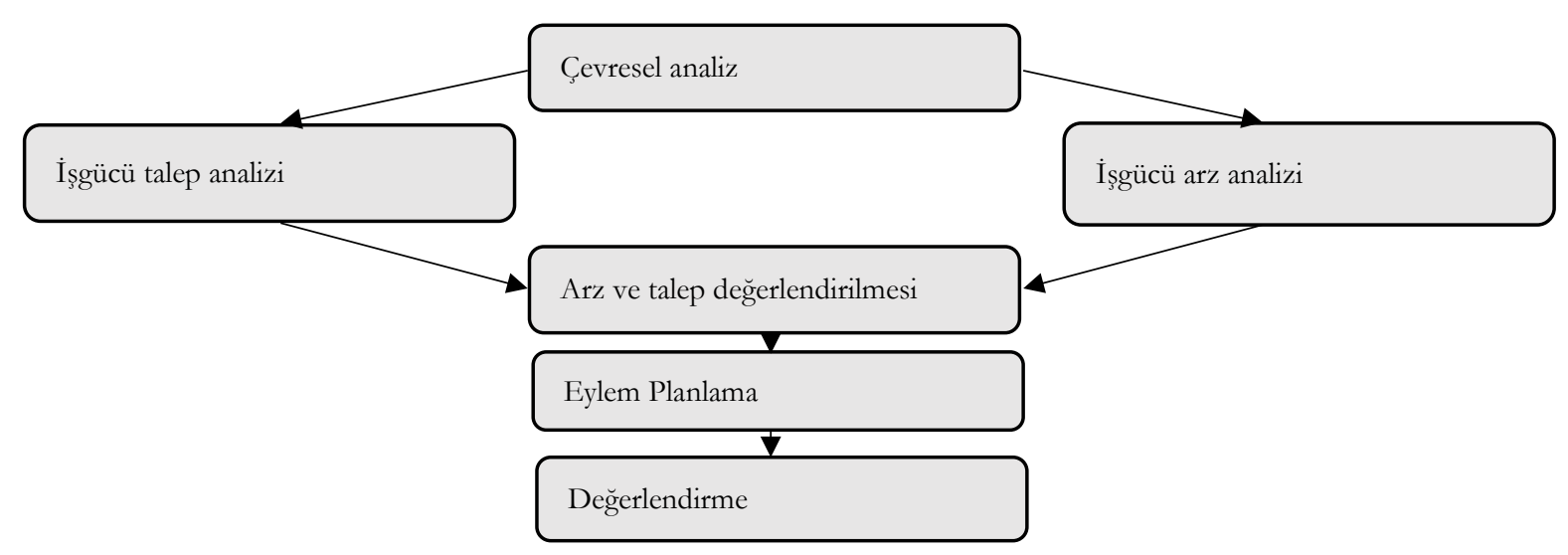

Şekil 4. Insan Kaynaklar Planlama Aşamalar

Kaynak: Demir, C. ve Güzel, B. (2005). Planlama. İçinde C. Demir. Konaklama işletmelerinde insan kaynaklarn yönetimi ilkeler ve uygulamalar (ss. 53-80). Ankara: Nobel Yayınc1lk.

İş analizi bir işin niteliğini, niceliğini, gereklerini ve çalışma koşullarını ortaya koyan çalışmadır. Personel ne yapıyor, işi nasıl yapıyor, işi yaparken hangi yardımcı araçları kullanıyor, hangi çıktılar sağlanıyor, hangi koşullarda yapılır ve işte ne tür yetenek, bilgi ve tecrübe gerekiyor sorularına verilecek yanıtlar iş analizinin sonuçları olacaktır (Geylan, 1996). Yapılan iş analizi sonucunda ise işin nasıl yapılacağını gösteren iş tanımları ve işin normal düzeyde yapılabilmesi için personelde bulunması gereken nitelikleri içeren iş gerekleri hazırlanır. Bu hazırlanan rapora işgücü envanteri denilir bu envanter çalışanların durum özetlerini gösterileceği grafiklerin çıkartılmasında ve durumun hızlıca görülebilmesinde oldukça faydalıdır (Temizkan, 2016, s. 131).

Personel devir oranının yüksek olması işletmelere özellikle personel maliyetlerinin artması, kalite ve verimliliğin düşmesi gibi olumsuz etkileri olmasına rağmen belirli oranlarda personel devir oranın ise işletmeye faydalarının olduğu yapılan çalışmalarla belirlenmiştir (Tuna, 2007). İşten çıkanların toplam sayısının ortalama personel sayısına oranı olan personel devir hızı, işletmenin yapısına, iş koluna, personel sayısına ve işletmenin büyüklüğüne göre değişik oranlarda olabilir (Sabuncuoğlu, 2000). Personel devir oranı aşağıdaki yöntemle hesaplanır.

\section{Personel Devir Oranı= İşten Çıkanlar/Ortalama Çalışan Sayısı*100}

Ortalama Çalışan Sayısı= Dönem Başı Çalışan Sayısı + Dönem Sonu Çalışan Sayısı/2

Turizm sektörü için önemli sorunlardan biri olarak kabul edilen personel devir oranlarının belirli oranlarda tutularak işletme dinamizminin ve verimliliğinin artırılmasının sağlanması önemlidir. Bu yüzden bu oranların turizm işletmelerinde insan kaynakları planlamalarında dikkate alınması oldukça önemlidir.

\section{Devamsızlık Oranı= Kaybedilen Toplam İşgücü Saati / Planlanan Toplam İşgücü Saati*100 (\% saat)}

Talep tahmininin doğruluk oranını arttıracak devamsızlık oranı ise; belirli bir faaliyet döneminde personelin işe geç gelmesi veya hiç gelmemesi sonucu olan devamsızlık nedeniyle kaybedilen çalışma saatlerinin planlanan çalışma saatlerine oranıdır. İzin ve yıllık tatiller bu kapsama dâhil edilmez (Yüksel, 2000; Tonus, 2013).

Ekonomik, sosyal, politik ve yasal değişiklikler, teknolojide yaşanan gelişmeler ve rekabet koşullarının değişmesi dış çevreyle ilgili bilgiler olup insan kaynakları talebinin belirlenmesinde dikkate alınmalıdır (Demir ve Güzel, 2005; Arslan, 2012: Tonus, 2013).

İnsan kaynaklarının planlama için kullandığı bu yöntemlerden iş analizi içinde değerlendirilebileceği düşünülen ve turizm işletmelerinin en önemli türlerinden biri olan otel işletmelerinde en yaygin planlama ölçütü olarak kullanılan bir yöntemde oda/yatak başına düşen personel oranıdır (Ağaoğlu, 1992). 


\section{Yatak Başına Düşen Personel Oranı= Personel Sayısı/Yatak Sayısı}

\section{Oda Başına Düşen Personel Sayısı= Personel Sayıs1/Oda Sayısı}

Uluslararası yapılan çalışmalar otel işletmelerinde yatak başına ortalama 0,5 personel düşmesi gerektiği sonucunu ortaya koymuştur. Ancak bu oran verilen hizmetin nicelik ve niteliğine göre farkllllk gösterebileceği gibi, personelin bölümler arasındaki dağlımı da bu oranın değişimine etki edebilir (Kozak, 2012: 63). Bu hesaplamalar ile işletme personel durumunu ne olduğunu ve neye ihtiyacı olduğunu daha kolay görebilecek ve planlamalarını gerçekleştirebilecektir.

İnsan kaynakları yönetimi planlama yaparken ileriye dönük bazı tahminlerde bulunmaktadır. Beceri gerektiren ve deneysel bir süreç olan tahminleme işlemlerinin (Bingöl, 2016, s. 175) doğru yapıllması büyük ölçüde insan kaynakları biriminin çalışmalarına bağlıdır. Bir işletmede işgücü talep tahminleri belirli bir iş kategorisi veya beceri alanı için yapılmaktadır. Gerekli olan beceri veya iş kategorisi gerekleri saptandıktan sonra planlamacilar her türlü talebi ayrıca değerlendirmelidir. İş gücü talep tahmininde nicel ve nitel olmak üzere iki yöntem kullanılmaktadır. Bu yöntemlere ilisskin bilgiler tablo 1 de verilmiştir.

Tablo 1. Issgü̈ü Talep Tahmininde Kullanulan Teknikler

\begin{tabular}{|c|c|c|}
\hline \multirow{2}{*}{ 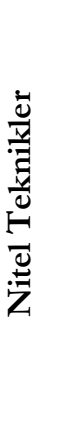 } & $\begin{array}{l}\text { Delphi } \\
\text { Yöntemi }\end{array}$ & $\begin{array}{l}\text { Öznel yöntemlerden biridir ve bir grup çalışması şeklinde gerçekleştirilir. Uzun } \\
\text { dönemli planlamada etkili olan bu yönteme göre belirli bir grup yöneticiden gelecek } \\
\text { dönemlere ait iş gücü talebine ilişkin görüş alınır. Her bir yönetici diğerlerinden } \\
\text { bağımsız bir biçimde soruları yanıtlar. Gelen cevaplar arasında önemli farklılıklar var } \\
\text { ise bunların nedenleriyle beraber tekrar yorum alınır. Bu şekilde görüş birliği } \\
\text { sağlanıncaya kadar devam eder. }\end{array}$ \\
\hline & $\begin{array}{l}\text { Nominal } \\
\text { Grup } \\
\text { Yöntemi }\end{array}$ & $\begin{array}{l}\text { Bir odada toplanan gruba gelecekteki insan kaynağı ihtiyacı ne olacak? Sorusu yöneltilir } \\
\text { ve yazılı olarak alınan cevaplar bir tahtaya yazılır. Ortaya çıkan sonuçlara ilişkin açık bir } \\
\text { tartışma gerçekleştirilir ve tartışma sonunda en çok kabul edilenden en aza doğru bir } \\
\text { sıralama yapılarak çoğunluk kararına göre bir tahminleme yapılmıs olur. }\end{array}$ \\
\hline \multirow{2}{*}{ 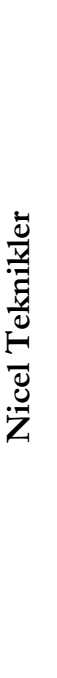 } & $\begin{array}{l}\text { Regresyon } \\
\text { Analizi }\end{array}$ & $\begin{array}{l}\text { Geçmişten elde var olan insan kaynakları bilgileri ile bir veya birden fazla geçmiş } \\
\text { ilişkilerin istatistiksel bir karşılaştırmasını yaparak işgücü ihtiyacının tahmin edilmesini } \\
\text { sağlar. Regresyon analizinde bilinen bir değişken ile bilinmeyen bir değişken arasındaki } \\
\text { ilişki matematiksel olarak formüle edilir ve bir tahminleme eşitliği oluşturulur. Örneğin } \\
\text { bir karşılayıcı acente yöneticisi gelen turist sayısını esas alarak çalışan sayısını tahmin } \\
\text { etmeye çalışır. Eğer gelen turist sayısı ve çalışan sayısı arasında önemli bir ilişki varsa; } \\
\text { gelecekteki transferman ve şoför gereksinmesini geçmiş yıllarda istihdam ettiği } \\
\text { personel ve transferi gerçekleştirilen turist sayısından hareketle gelecekteki muhtemel } \\
\text { turist sayısına göre istihdam ihtiyacını tahmin edebilir. }\end{array}$ \\
\hline & Trend Analizi & $\begin{array}{l}\text { İşletmedeki istihdam seviyesinin geçmiş birkaç yll (genellikle beş y1l) verileri incelenir. } \\
\text { Bu verilerden hareketle ileriye dönük tahminler gerçekleştirilir. İleriye dönük } \\
\text { tahminlerde genellikle beş yılllk süre için yapılır. Burada amaç gelecekte devam edecek } \\
\text { eğilimi belirlemektir. Bu veriler geleceğe yönelik tahminlerde yardımcı olabilir ancak } \\
\text { personel ihtiyacındaki değişim ile zaman arasındaki ilişki nadiren doğrusal ve } \\
\text { kesintisizdir. Bu yüzden turizm sektörü gibi talebin oldukça esnek olduğu sektörlerde } \\
\text { bu yöntemin verimli olması çok zordur. }\end{array}$ \\
\hline
\end{tabular}

Kaynak: Demir ve Güzel, 2005; Sabuncuoğlu, 2009; Tortop vd. 2010; Gomez-Meija vd., 2012; Bingöl, 2016; Temizkan, 2016.

İşgücü talep ve arzının planlamasına ilişkin nitel teknikler karar vericilerin yargısal kararlarına bağlıdır (Torrington vd. 2017, s. 97). Bu yaklaşımın odak noktası, bir kurumdaki insan kaynakları fazlasını ve eksikliklerini tahmin etmektir. Bu yöntemin kullanımı yönetici ve uzman pozisyonlarındaki çalısanların deneyim ve bu deneyimlere dayalı sezgileri ile örgüt planlarına dayanarak işgücü tahmininde bulunmayı sağlar. Değerlendirilecek durumlar konusunda oldukça esnek ve kapsamlı olan bu tekniklerin dezavantaj1 ise nicel hesaplamalara oranla daha düşük doğruluk derecelerine sahip olmalarıdır (Gomez-Meija vd., 2012). 
Nicel teknikler, geçmiş dönemlerde elde edilen verilerden istatistiksel yöntemler ile geleceğe ilişkin tahminlerde bulunulur. Nitel tekniklere göre daha yaygin olarak kullanilan bu tekniklerin en önemli kısıtlayıcısı ise üst seviye uzmanlık gerektirmesi ve geçmişte yaşanan durumların, günümüzün hızlı değişen dünyasında tekrar etme ihtimalin düşük olmasıdır (Demir ve Güzel, 2005; Bingöl, 2016).

İşgücü talebinin tahmin edilmesinden sonra işgücü arzının da tahminlenmesi gerekmektedir. İşgücü arz1 tahminlenmesi, işletmede mevcut çalışanlardan oluşan işletme içi arz kaynağı ve işletme dişında bulunan iş arayanların ya da başka işletmelerde çalışanların oluşturduğu işletme dışı arz kaynağı olmak üzere iki şekilde ele alınmaktadır (Pilbeam ve Corbridege, 2010; 93-95). İşletme içi arz kaynağının geleceğe yönelik eğilimleri işgücü envanteri sayesinde hesaplanabilmektedir. Ancak işletme içindeki çalşsan hareketlerini de görebilmek için işe alma, işten çıarma, transfer, ücretleme, geliştirme gibi uygulamalarda göz önünde bulundurulmalıdır. İşletme dışı arz kaynağını etkileyen faktörler ise genel ekonomik durum, yerel pazarın durumu ve mesleki pazar durumudur (Torrington vd. 2017). Bu yüzden bu konulardaki istatistiki verilerin doğruluğu oldukça önemlidir. İşücü arzının tahminlenmesinde kullanılan yöntemler nicel yöntemlerdir ve tablo 2 de belirtilmiştir.

Tablo 2. Isgücü Arz Tabmininde Kullamlan Teknikler

\begin{tabular}{|c|c|}
\hline $\begin{array}{l}\text { Simulasyon } \\
\text { Tekniği }\end{array}$ & $\begin{array}{l}\text { Gelecekte ortaya çıkacak istihdam seviyelerini belirlemede kullanılan uzun dönem tahmin } \\
\text { yöntemidir. Sanal olarak oluşturulan bir ortamda işletmenin gelecekteki durumuna yönelik } \\
\text { alternatif kararlar alınarak çeşitli varyasyonların sonuçları değerlendirilir. }\end{array}$ \\
\hline $\begin{array}{l}\text { Bilgisayar } \\
\text { Destekli Bilgi } \\
\text { Sistemi }\end{array}$ & $\begin{array}{l}\text { İşletmedeki çalışan hareketliliğini izleyen bir bilgi sisteminin kurulması ve tüm birimlerce } \\
\text { kullanılabilir hale getirilmesi işgücü tahminde önemli bir veri kaynağı oluşturmaktadır. Bu } \\
\text { sistemde çalışanlara ilişkin aldığı eğitimler, çalıştığı birimler, performans sonuçları, üretimde } \\
\text { birim başına saatlik işçilik maliyetleri ve kariyer planlamada öngörülen pozisyonlar gibi } \\
\text { verilerden yola çıkarak geleceğe ilişkin projeksiyonlar yapmayı, üretimdeki artışların işgücü } \\
\text { ihtiyacını ve maliyetleri nasıl etkileyeceğini görmeyi kolaylaştırmaktadır. }\end{array}$ \\
\hline $\begin{array}{l}\text { Markov } \\
\text { Analizi }\end{array}$ & $\begin{array}{l}\text { İşletme içi iş adaylarının varlı̆̆ını tahminlemek için kullanılan matematiksel bir tekniktir. İşletme } \\
\text { içinde daima bölümler arasında, işletme dışına ya da işletmeye geçişler olabilmektedir. Markov } \\
\text { analizi bu türdeki çalışan hareketlerinin analiz edilmesi sayesinde işletme de genel olarak değil } \\
\text { bölümler bazında bir işgücü planlamasının yapılmasını sağlamaktadır. Markov analizi sadece } \\
\text { büyük işletmelerde kullanılabilen bir yöntemdir. Bunun sebebi analizin yapılabilmesi için } \\
\text { herhangi bir iş bölümünde en az } 50 \text { kişinin bulunması gerekliliğidir. }\end{array}$ \\
\hline
\end{tabular}

Kaynak: Demir ve Güzel, 2005; Sabuncuoğlu, 2009; Tortop vd. 2010; Gomez-Meija vd., 2012; Bingöl, 2016.

İnsan kaynakları talebi ve arzı belirlendikten sonra karşılaştırılması gerekmektedir. İnsan kaynakları arzının talepten az olduğu durumlarda mevcut personel eğitilebilir, vardiya sayısı arttırılabilir, fazla mesai oluşturulabilir veya yeni personel alınabilir. Tersi durumda ise personeli elden çıarma maliyetine, işletmenin amaçlarının revize edilip edilemeyeceğine ve iş hacminde oluşabilecek artışlara bakılmalı ve en rasyonel karar verilmelidir (Güler, 2017). Turizm işletmeleri, diğer insan kaynakları işlevlerine geçmeden önce mutlaka işgücü talep ve arzını ve bunların temin kaynaklarını net bir şekilde ortay koyan işgücü analizlerini içeren iyi bir insan kaynakları planlaması yapmak zorundadırlar. Çünkü hangi sayıda ve nitelikte çalsşan ihtiyacı olduğu bilinmeden insan kaynakları işlevlerini yerine getirmek mümkün değildir (Erdem, 2004, s. 44).

Turizm işletmelerinde insan unsurunun iyi yönetilmesi işgücünün verimli kullanılmasını sağlayacaktır. Otel, seyahat, yiyecek içecek ve rekreasyon işletmeleri gibi, karşılıklı ilişkilerin ve insanın insana hizmeti olgusunun en yoğun yaşandığı işletmelerde insan unsurunun yönetilmesi, ancak iyi bir planlama ve bu alanda uzmanlık gerektiren insan kaynakları yönetimi ile gerçekleştirilebilir. Turizm işletmeleri açısından insan kaynakları planlaması, verimliliği etkileyen ve belirleyen temel unsurlardan biridir. Çünkü insan kaynakları planlaması sadece çalışan sayısını planlayarak tasarruf etmeyi değil, aynı zamanda işin niteliğine uygun çalşsanların belirlenmesini, seçimini ve istihdamını da sağlayarak müşterilere sunulan hizmetin kalitesinin artırlmasında da etkili olur (Kaynak, 1990, s. 7). 


\section{Turizm İşletmelerinde İnsan Kaynakları Planlaması ile İlgili Sorunlar ve Çözüm Önerileri}

Planlama daha önce de belirtildiği gibi uzun bir zamanı kapsadığı ve geleceğe doğru olduğundan, insan kaynakları planlaması daha karmaşık bir hal almaktadır. Bu konuda acemi olan işletmelerin daha fazla hata yapma olasıllı̆̆ ortaya çıkmaktadır. Bu nedenle aşağıdaki bahsedilen sorunlar geçmeden önce temel sorun olarak bunu belirterek bu konuda işletmelere daha kısa dönemli planlama faaliyetlerinde uzman olduktan sonra uzun vadeli planlama faaliyetlerine dâhil olmaları gerektiği söylenebilir (Jackson ve Schuler, 1990).

Etkili bir insan kaynakları planlaması gerçekleştirilirken işletme çeşitli zorluklar ve sorunlarla karşılaşmaktadır. Bu sorunlardan bir tanesi talep ve arz arasındaki farklardır. Ortaya çıkan bu fark, işletmede insan kaynaklarına yönelik olarak faaliyet programlaması sırasında alınacak önlemler ile arz ve talep arasındaki denge kurulabilir (Arslan, 2012).

Arslan'a (2012) göre faaliyet programlaması insan kaynaklarının tüm fonksiyonlarını kapsayan çok yönlü çalısmadır. Faaliyet programlaması kapsamında fonksiyonların hepsinin bir yeri vardır, ancak bu kapsamda ilişki yoğunluğu en fazla olan fonksiyonlar; işe alma ve yerleştirme, eğitim ve geliştirme, kariyer yönetimi ve işten ayırma fonksiyonlarıdır. Faaliyet programlamasının yoğunlaşacağı konular arz ve talep karşılaştırmasına bakılarak belirlenebilir. Bu karşılaştırma sonucunda işletmenin insan kaynakları gereksinimi olduğu ortaya çıkmıssa aday toplama, seçme, uyumlaştırma ve gereksinim duyulan elemanlara eğitim verme üzerine yoğunlaşması beklenir. Bunun tersi olarak insan kaynaklarına da bir azaltma gerekliliği var ise, bu sefer de faaliyet programlarının işletmenin insan kaynaklarına yönelik gerekli ayarlamaları yapmak üzerine yoğunlaşması gerekir. Bununla ilgili olarak turizm işletmelerinden bir örnek vermek gerekirse; mevsimsellik özelliğinin yüksek olduğu bölgelerde faaliyet gösteren turizm ișletmeleri, sezonun başladığı dönemlerde işgücü talebi arzdan yüksek olduğu için aday toplama, seçme, uyumlaştırma ve eğitim verme faaliyetlerine yoğunlaşırlar. Örneğin sezon öncesinde yüksek eğitim kurumların ziyaret eden, stant kuran ya da okul sektör buluşmalarına katılan işletmeler buralardan aday toplayıp, seçim yaparak sezon öncesi bu öğrencilere gerekli eğitimleri vermektedirler. Bunun tersini yaşandığı dönemlerde ise işten çıkartılacakların sayısı ve tarihi, tazminat işlemleri gibi işlemleri gerçekleştirirler.

Turizm işletmelerinin planlamaya ilişkin karşılaştıkları bir başka önemli sorun ise işveren ve çalışanların beklentilerinin birbiriyle uyumlu olmamasıdır. Türkiye özelinde durum ele alındığında, turizm işletmeleri yöneticileri insan kaynağını önemli bir maliyet unsuru olarak görmekte ve tasarruf tedbirlerinin uygulanması gereken durumlarda, öncelikli tasarruf tedbiri olarak çalışan sayılarını azaltma yoluna gitmektedir (Erdem ve Tokmak, 2015: 185). Ancak bu durumun geçici olarak tasarruf sağlasa bile sonraki dönemlerde yeniden işgücü bulma, seçme, uyumlaştırma ve eğitme süreçlerinin işletme için daha büyük maliyetlere katlanmayı gerektirdiği göz ardı edilmektedir. Bununla beraber eğitilmiş ve deneyimli işgücünden alınacak verim ve yaratacağı müşteri memnuniyeti de (Gunarathne, 2014; Della Corte vd. 2015) büyük ölçüde kesintiye uğramaktadır. Ayrıca bir başka önemli konu, işletmeler verimliliklerini artırmak için diğer işletmelerden pek çok şeyi kendi işletmelerine kopyalayabilir ve kullanabilir. Turizm işletmeleri için verimliliğe etki eden en önemli unsur olan insan kaynakları (Delery ve Doty, 1996; Becker ve Huselid, 1998) ise diğer işletmeler tarafindan kopyalanabilecek ve kısa sürede yetiştirilebilecek bir kaynak değildir (Barney ve Wright, 1998). Turizm işletmeleri için bu tür sorunların tamamen ortadan kaldırılması belki mümkün olmayabilir ancak insan kaynakları birimlerinin çalışanların performans değerlendirmelerini özenli ve gerçekçi bir zeminde yapmaları (Pelit ve Çetin, 2019) ile işletme için önemi fazla personellerin belirlenerek elde tutulması yoluna gidilebilir. Sürdürülebilir rekabetin sağlanması kaliteli işgücünün işletme tarafından korunmasına bağlıdır.

İnsan kaynakları planlamasında karşılaşılan ve turizm işletmelerinin de en önemli sorunlarından biri olan, işin gereği sahip olunması gereken beceriler ve başvuranlar arasındaki uyumsuzluktur. Bunun nedenleri işyerinin mevcut işgücü arzından daha fazla işgücü talep etmesi veya daha farklı işgücüne ihtiyaç duyması ya da işletmenin işe alım stratejilerinin doğru işgücünü işletmeye çekmemesi olabilir. Bu durum işletmenin operasyonel hedeflere ulaşmak için kritik olan pozisyonları nitelikli ve uygun personel ile dolduramamasina ve işletmenin pozisyonunun zayiflamasina neden olur (Bianca, 2017). Turizm işletmelerinin maliyet kaygılarıyla nitelikli personel almaktan kaçınması (Örücü, 2002, s. 131) ya da nitelikli personel için cazip olabilecek imkânları sağlamaması sektörde sıkça rastlanılan bir durumdur. Bu nedenle, insan kaynakları ihtiyaçlarının tahmin edilmesi, çalışanların etkili bir şekilde işe alınması, değiştirilmesi ve korunması insan kaynakları birimlerince izlenmeli ve üst yönetim ile bilgi paylaşımı gerçekleştirilmelidir. 
İşletmenin büyüklüğü ve yapısının karmaşıklığı insan kaynakları planlamasını zorlaştıran unsurlardan biridir. Genellikle büyük işletmelerde planlamayla ilgili olarak bulma, seçme ve yerleştirme gibi faaliyetler ve sonrasındaki eğitim ve uyumlaştırma uzun ve çeşitli aşamalardan oluşmaktadır (Saruhan ve Yıldız, 2012, s. 269). Büyük çaplı işletmelerde planlama sürekli bir biçimde hem birim hem de işletme çapında gerçekleştirilmelidir. Örneğin büyük ölçekli konaklama işletmelerinde insan kaynağı planlaması yapılırken insan kaynağına olan talebin karşılanacağı iç ve dış kaynaklar iyi belirlenmeli işletme içi arz kaynaklarında düşük sezonda eğitim ve rotasyonlar uygulanarak acil durum ihtiyaçlarını karşılayabilecek personel hazır tutulmalıdır. Planlama periyodları daha sık gerçekleştirilmeli ve departmanlardan personel ile ilgili bilgi akışı sürekli hale getirilmelidir.

İşletmeler açısından insan kaynakları planlamasında yaşanan sorunlardan bir diğeri de genel işletme stratejilerini güçlendirecek planların hazırlanamamasıdır. Bunun nedenlerinden bazıları şu şekilde ifade edilebilir (Gomez-Meija vd. 2011); Üst yönetim her zaman işletme stratejilerini açık bir şekilde dile getirmeyebilir, Genel iş stratejisini desteklemek için hangi insan kaynakları stratejilerinin kullanılması gerektiğine dair belirsizlikler veya anlaşmazlıklar olabilir. Yani insan kaynakları stratejilerinin örgütsel stratejilerin başarısına nasıl katkıda bulunacağı belirli olmayabilir. Üçüncü olarak, büyük şirketlerde her biri kendi iş stratejilerine sahip, farklı iş birimleri olabilir. Turizm işletmeleri açısından işletme genel stratejilerini güçlendirecek insan kaynakları planlarının oluşturulması için stratejik planlamalar yapılırken, insan kaynakları yöneticilerini bu süreçlere dâhil edilmesi ile yanlış anlaşılma ya da bilgi eksikliği sorunları minimize edilebilir. İnsan kaynakları yöneticilerinin insan kaynakları stratejilerini belirlerken her bir stratejinin işletme stratejisine katkısı göstergeleri ile birlikte belirlenirse sürecin takibi de kolay olacaktır. Konaklama işletmeleri içindeki departmanlarının birim stratejileri oluşturulurken insan kaynakları yönetimiyle birlikte hareket edilmesi gereklidir.

Turizm işletmelerinin yapmakta olduğu önemli hatalardan biri de, en iyi olduğu düşünülen ya da popüler insan kaynakları uygulamalarının ve stratejilerinin işletmeye doğrudan uyarlanmaya çalışılmasıdır. Ancak örgütsel yapılara uymayan herhangi bir en iyi insan kaynakları uygulamasının dahi başarısız olma ihtimali yüksektir. Çünkü örgütler, kültürleri, liderlik yapıları, teknoloji kullanımları, tarihleri vb. pekçok unsur sebebiyle asla aynı değillerdir ve aynı uygulamalar aynı sonuçlar vermez (Gomez-Meija vd. 2011). Örneğin karşıladıkları yolcu sayısı aynı olsa bile, İngiliz tur operatörlere hizmet veren bir karşılayıcı acentenin planladığı araç doluluk oranı ve personel miktarı ile Alman tur operatörlerle çalışan bir acentenin araç doluluk oranları ve personel sayısı farklı olmalıdır.

Turizm işletmelerinde işgören devir hızının yüksek olması (Aydın, 2005, s. 265) insan kaynakları planlaması açısından önemli sorunlardan biridir. İşgören devri işletmenin faaliyet ve planlarını önemli ölçüde etkileyen bir durumdur (Erdem ve Tokmak, 2015, s. 187). İşgören devir hızını etkileyen işletme içi ve işletmeden bağımsız pek çok faktörden söz edilebilir. Ancak bunları; çalışanlardan kaynaklanan etkenler (kişisel beklentiler), yönetimden kaynaklanan etkenler (işten çıkarma vb.) ve sektörel etkenler (turizmin mevsimlik özelliği nedeniyle düşük sezonda işletmelerin kapanması) şeklinde üç ana başlıkta toplamak mümkündür (Günel, 2009, s. 110). Turizm işletmelerinin diş faktörlere karşı doğrudan müdahale imkânları olmasa bile üye oldukları birlikler aracilğıyla bu konularda devlet kurumlarının düzenleme yapmasına yönelik öneriler getirmeleri mümkündür. İç faktörlere ilişkin ise çalsşan beklenti ve isteklerinin daha iyi anlaşılması ve işletme için önemi yüksek personelin elde tutulmasına ilişkin uygulamaların geliştirilmesi gibi önlemler alınabilir. Bu önlemler arasında bazı işletmelerin piyasalardaki geçici daralmalarda geçici olarak çalışanları işten çıkarmalarında uyguladıkları bazı uygulamalar göz önüne alınabilir. Örneğin düşük sezonda işten çıarılması gereken personelin sosyal güvenlik primleri yatırılmaya devam edilebilir. İşten çıarma süreleri azaltılabilir örneğin 4 ay yerine 2 aya düşürülüp daha az maaşlar ödenebilir. Mevsimselliğin azaltılması yönünde yine devlet kurumları ile koordine şekilde yıllık tatil planlamaları, ucuz ulaşım imkânları gibi iç turizmin canlandırılmasına yönelik adımlar atılabilir (Erdem ve Tokmak, 2015, s. 188).

$\mathrm{Bu}$ sorunların yanında planlama dikkatli ve sürekli yapılsa bile, uygulamada sağlıklı bir şekilde yapılmasına engel olan faktörler ortaya çıkacaktır. Bu faktörler aşağıda Tablo 3'de çözüm önerileri ve bu çözümlerde insan kaynakları birimini rolü ile birlikte verilmeye çalısıllmıştır. 
Tablo 3. Insan Kaynaklar Planlamasında Ortaya Cıkabilecek Diğer Sorunlar ve Çöæüm Önerileri

\begin{tabular}{|c|c|c|}
\hline Sorunlar & $\begin{array}{c}\text { Sorunların Çözümünde İnsan Kaynakları } \\
\text { Yönetimi (İKY) Biriminin Rolü }\end{array}$ & $\begin{array}{c}\text { İşletme ve İKY birimlerine Olası Çözüm } \\
\text { Önerileri }\end{array}$ \\
\hline $\begin{array}{l}\text { İnsan Kaynakları } \\
\text { planlamasinda } \\
\text { tahminlerin yanılma } \\
\text { tehlikesi }\end{array}$ & $\begin{array}{l}\text { Özellikle yüksek işsizlik dönemlerinde sosyal ve } \\
\text { ekonomik değişiklikleri doğru olarak tahminleme } \\
\text { zorluğu. Mevcut ve gelecekteki eğilimleri doğru bir } \\
\text { şekilde takip etmek ve aynı şeyi anlaml eylem } \\
\text { kurallarına dönüştürmenin her zaman mümkün } \\
\text { olmaması. Çok uzun süreli ve uzun aralıklı planların } \\
\text { yanılma riskinin yüksek olması gibi sebeplerle ortaya } \\
\text { çıan bu sorunda İnsan kaynakları yöneticilerinin } \\
\text { hedefler ve göstergelerini net belirlemeleri ve ara } \\
\text { planlamalar için üst yönetimle hareket etmeleri } \\
\text { gerekir }\end{array}$ & $\begin{array}{l}\text { İnsan kaynaklar1 planlamaları stratejik } \\
\text { planların yanında ara planlamalar da } \\
\text { uygulayarak daha stk aralılarla } \\
\text { gerçekleştirilmeli ve denetlenebilir, somut } \\
\text { göstergeler belirlenerek bunlar kontro } \\
\text { edilmelidir. }\end{array}$ \\
\hline $\begin{array}{lr}\text { Üst } & \text { yönetimin } \\
\text { desteğinin } & \text { eksikliği, } \\
\text { Yönetim } & \text { üyeleri } \\
\text { arasinda muhalefet } \\
\text { veya şüphecilik }\end{array}$ & $\begin{array}{l}\text { İnsan kaynakları planlama süreçlerinde hat } \\
\text { yöneticilerinin ve/veya üst yönetimin katılmaması, } \\
\text { planların işletme stratejilerine desteğinin açık olarak } \\
\text { belirtilmemesi ve yüksek maliyet gibi sebepler bu } \\
\text { soruna neden olur. Dolayısıyla bu sorunun ortaya } \\
\text { çıkmaması için insan kaynakları yöneticilerinin işletme } \\
\text { yöneticileri arasında iyi koordinasyon oluşturması, } \\
\text { etkili iletişim sağlaması ve planlama çalışmaları zaman } \\
\text { çizelgelerini herkesin katıllımını sağlayacak şekilde } \\
\text { yapması gerekir. }\end{array}$ & $\begin{array}{l}\text { Tüm üyelerin insan kaynakları planlamasının } \\
\text { değeri hakkında ikna edilmeleri, ayrıca hat } \\
\text { yöneticilerinin planlama sürecinde ro } \\
\text { almaları gerekir. Planlama sürecinde herkes } \\
\text { ikna edecek gerekçeler açk şeklinde ifade } \\
\text { edilmelidir. }\end{array}$ \\
\hline $\begin{array}{lr}\text { Geriye yönelik } & \text { tam } \\
\text { ve doğru } & \text { personel } \\
\text { kayitlarına } & \text { sahip } \\
\text { olmama } & \end{array}$ & $\begin{array}{l}\text { İ̧sletmelerin geçmiş dönem kayıtlarının tutulması ve } \\
\text { arşivlenmesi konusunda yeterince titiz } \\
\text { davranmamaları, uygun bir dosyalama sisteminin } \\
\text { işletmede kurulmamış olması ve dijital dosyalama için } \\
\text { uygun yazıllımların kullanılmıor olması bu sorunun } \\
\text { temel sebebidir. Bir işletmede insan kaynakları } \\
\text { yönetimi göreve gelir gelmez arşiv ve kayıtları kontrol } \\
\text { edip verimli bir dosyalama sisteminin hayata } \\
\text { geçirilmesini sağlamalıdır. }\end{array}$ & $\begin{array}{l}\text { İşletmeler yapılarına göre kendilerine uygun } \\
\text { bir dosyalama ve arşiv sistemi oluşturmalı ve } \\
\text { her birimde bu konudan sorumlu bir kiş̧ } \\
\text { bulunmalıdır. Sadece muhasebe kayıtları ve } \\
\text { hukuki zorunluluktan doğan evraklar deği } \\
\text { insan kaynakları ile ilgili diğer tüm kayıtlar } \\
\text { düzenli olarak saklanmalıdır. }\end{array}$ \\
\hline $\begin{array}{l}\text { Lider eksikliği ya da } \\
\text { liderin bütün işsi } \\
\text { yapacağı inanc1 }\end{array}$ & $\begin{array}{l}\text { İşletmelerde lider sadece bir sıfat değil tüm ekibin } \\
\text { işletme vizyonunu ve hedeflerini tüm ekibin daha net } \\
\text { şekilde anlamasını sağlayacak önemli bir kavramdır. } \\
\text { İşletmelerde lider ve yönetici kavramlarının tam } \\
\text { olarak anlaşılmamıs olması her yöneticinin kendini } \\
\text { lider olarak görmesi ancak liderlik vasıflarına sahip } \\
\text { olmaması kararları tek başına almaya çalışması ve her } \\
\text { şeye müdahale etmesi bu sorunun ortaya çıkş̧ } \\
\text { nedenidir. Bu yüzden insan kaynakları yönetimi } \\
\text { planlama aşamasına geçmeden, yapılan iş analizlerinde } \\
\text { her işin gereklerini belirlerken bu işleri yapacak birim } \\
\text { yöneticilerinin yetki ve sorumluluklarını da } \\
\text { belirleyerek bunları açı şekilde raporlarında } \\
\text { belirtmelidir. }\end{array}$ & $\begin{array}{l}\text { Liderlik yöneliminin örgütsel özelliklere göre } \\
\text { değissiklik göstermesi nedeniyle liderliğin } \\
\text { etkili olabilmesi için örgüt tipi ve örgüt } \\
\text { hiyerarşisi ile uyumlu olması gerekmektedir. } \\
\text { Özellikle turizm işletmelerinde departmanla } \\
\text { arası yönetici yaklaşımlarını çok cidd } \\
\text { farklılıklar göstermesi işletme içinde denge ve } \\
\text { uyumu azaltacağından ve bununda müşteriye } \\
\text { yansıması mutlak olacağından gerekli uyarılar } \\
\text { önemle yapılmalı ve sürekli gözlemler } \\
\text { yapılmalıdır. }\end{array}$ \\
\hline $\begin{array}{l}\text { Sayıların, niteliğin } \\
\text { önüne geçmesi }\end{array}$ & $\begin{array}{l}\text { İşletme içinde insan gücü planlaması yapılırken iş } \\
\text { analizlerine uygun personelden ziyade yeter sayılar } \\
\text { üzerinde durulması ve gerekli eğitim tecrübenin göz } \\
\text { ardı edilmesi bu sorunun temel kaynağıdır. Insan } \\
\text { kaynakları yöneticileri her iş için gerekli nitelikleri } \\
\text { belirlemeli ve bu vasıflara sahip kişilerin temini için } \\
\text { çalışmalıdır. }\end{array}$ & $\begin{array}{l}\text { İş analizlerinin düzgün yapılarak iş } \\
\text { gereklerine uygun nitelikte persone } \\
\text { belirlenmelidir. Unutulmamalıdı ki her } \\
\text { zaman yeterli sayıa sahip olmak işin } \\
\text { gerektiği gibi yapılacağ anlamına } \\
\text { gelmeyebilir. Örneğin ön büroya } 4 \text { adet } \\
\text { resepsiyon personeli alınacaksa bu } 4 \\
\text { personelin eğitimleri, yabancı dil seviyeleri, } \\
\text { tecrübeleri aynı olabilir ancak bu kişilerin } \\
\text { hepsinin iletişim becerileri, duygusal emek } \\
\text { düzeyleri aynılmayabilir. Böyle bir durumda } \\
\text { dört tane personel almak resepsiyondak } \\
\text { personel ihtiyacinı tam olarak karşılamıs } \\
\text { olmayacaktır. }\end{array}$ \\
\hline
\end{tabular}


Tablo 3 - Devam

\begin{tabular}{|c|c|}
\hline Sorunlar & $\begin{array}{c}\text { Sorunların Çözümünde İnsan Kaynakları } \\
\text { Yönetimi (İKY) Biriminin Rolü }\end{array}$ \\
\hline $\begin{array}{l}\text { Kisitli zaman } \\
\text { yüksek masraflar }\end{array}$ & $\begin{array}{l}\text { İnsan gücü planlaması zaman alıcı ve pahalı bir } \\
\text { süreçtir. Veri toplama ve tahmin etme konusunda } \\
\text { azımsanamayacak zaman ve maliyet söz konusudur. } \\
\text { Dolayısıyla üst yönetim bu zamanı ve maliyeti göz } \\
\text { önünde bulundurarak işleri daha kestirme şekilde } \\
\text { halletme yaklaşımı gösterebilir. Ancak bu durum uzun } \\
\text { vadede işletmeye daha büyük maliyetler yaratacaktır. } \\
\text { Bu yüzden insan kaynakları yönetiminin durumu üst } \\
\text { yönetime ikna edici şekilde izah etmesi ve yine işletme } \\
\text { çıarlarını da gözeterek gerekli maliyet ve zaman } \\
\text { hesaplamalarını net bir şekilde yapması ve bunu } \\
\text { yönetime rapor etmesi gerekir. }\end{array}$ \\
\hline
\end{tabular}

İşletme ve İKY birimlerine Olası Çözüm Önerileri

Harcanan zaman ve paranın geri dönüşümünün işletme için daha önemli olduğunun tüm kesimlerce anlaşılması için çalışmaların yapılması gereklidir. Düşünüldüğü zaman turizm işletmelerinin gelecek planlamasında insan faktörünü göz ardı etmek mümkün değildir. Geleceği inşa edeceği temelleri sağlam atmayan, sektördeki yeniliklere ayak uyduramayan, günün gereği yetkinliklere sahip olamayan insanlarla işletme kendini geleceğe taşıyamaz. Bu yüzden iş analizleri, işletme içi kaynaklar ve diş kaynakların en iyi şekilde değerlendirilmesi bununla birlikte piyasaların, tüketicilerin ve sektörün durumu ve trendler iyi analiz edilerek gerekli adımların atılması önemlidir.

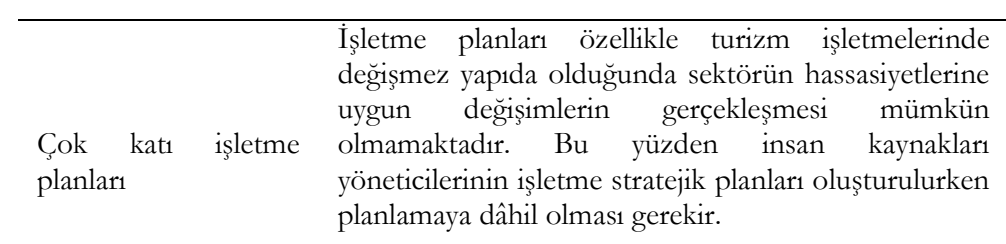

Esnek olmayan bir stratejik plana sahip bir firma, belirli bir hareket tarzına bağlı olduğu için, değişikliklere hızlı bir şekilde cevap veremez. Bu yüzden stratejik bir vizyon oluşturmak ve değişime ayak uydurmak için esnek planların oluşturulması sektörün iniş çıkışları ve genel durumunun takip edilmesi gereklidir.

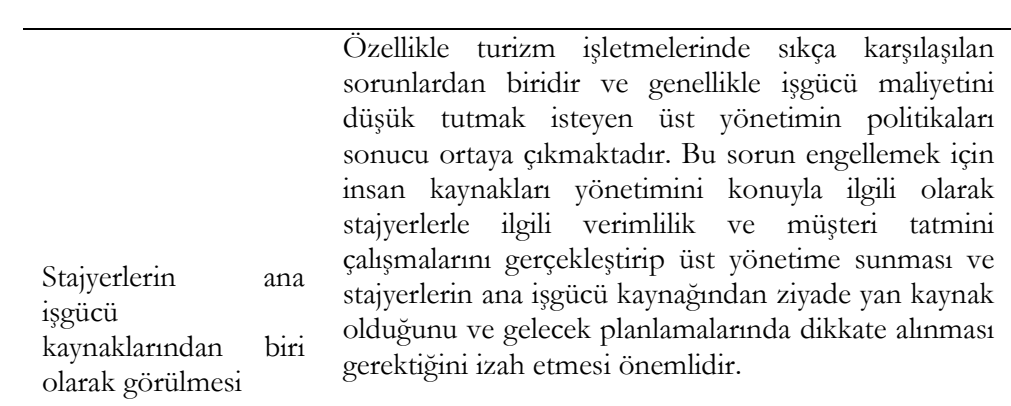
Stajyer ögrencilerin turizm işletmelerinde işgücünün azımsanamayacak bir bölümün oluşturduğu bir gerçektir. Ancak stajyerler henüz eğitim görmekte olan ve gelecek planlamasinda göz önünde bulundurulması gereken, henüz yeterli birikim ve tecrübeye sahip olmayan genç insanların oluşturduğu bir gruptur. Bu yüzden bu öğrenciler işletmenin gelecekte kullanabileceği ve buna uygun olarak gerekli işbaşı eğitimlerin işletme içinde iş ile beraber verilmesi gerektiği unutulmamalıdır. Bu öğrencilerin işletme kültürünü benimseyebilmeleri ve yeterli tecrübeyi edinebilmeleri için çalışmalar gerçekleştirilmeli onlardan potansiyellerinin üzerinde verim beklenerek hareket edilmemelidir.

Stajyerler ile ilgili bir başka sorun da stajyerlerin staj sürelerini tamamlayamadan işten çıkartılmaları ya da ayrilmalarıdır. Aslında bu sorun üstteki sorun ile bağlantılı bir sorundur. Çünkü ana iş gücü olarak görülen stajyerden işletmenin beklentisi daha yüksek olmakta ve bu beklentiyi karşılayamadığı düşünülen ya da çok sık hata yapan stajyer işten Stajyerlerin staj çıkartılabilmektedir. Stajyerin işten ayrılması ise, sürelerini kendisinden çok şey beklendiğini düşünen stajyer doldurmadan işten üzerinde çok fazla iş yükü ve baskı hissetmekte yaşı ayrılmaları ya da işten ve tecrübesi bunu kaldırmaya yetmediği içinde işten çıkartılmaları
Stajyer ögrencilerin yukarıda da bahsedildiği gibi ana işgücü olarak değil eğitim aşamasında genç insanlar olduğunun dikkate alınması, stajları süresince eğitimleri yanında sektöre isınmalarını sağlayacak faaliyetler gerçekleştirilebilir. Bunun yanında insan kaynakları biriminin stajyerler için özel oryantasyon eğitimleri ve danışmanlık ve rehberlik hizmeti vermesi sağlanabilir. Çünkü bu insanlar sadece işletme için değil sektörün geleceği içinde önem arz etmektedir. 
Tablo 3-Devam

\begin{tabular}{|c|c|c|}
\hline Sorunlar & $\begin{array}{c}\text { Sorunların Çözümünde İnsan Kaynakları } \\
\text { Yönetimi (İKY) Biriminin Rolü }\end{array}$ & $\begin{array}{l}\text { İşletme ve İKY birimlerine Olası Çözüm } \\
\text { Önerileri }\end{array}$ \\
\hline $\begin{array}{l}\text { Nesiller arasındaki iş } \\
\text { değerlerinin } \\
\text { planlamada dikkate } \\
\text { alınmaması }\end{array}$ & $\begin{array}{l}\text { Yönetim, motivasyon ve değer üzerine yapılan pek } \\
\text { çok çalışmada çeşitli kuşaklar arasında beklentilerin ve } \\
\text { iş değerlerinin oldukça farklı olduğu ortaya çıkmıştır. } \\
\text { Bu farklılıklar özellikle turizm işletmeleri gibi 15-16 } \\
\text { yaşında stajyerler ile } 50 \text { yaşında ve daha büyük } \\
\text { kişilerin bir arada çalıştığı işletmelerde daha büyük } \\
\text { boyutlarda yaşanmaktadır. Insan kaynakları birimleri } \\
\text { bu tür farklılıklardan doğabilecek sorunların } \\
\text { önlenmesi için işletme içerisinde çalışanlara ilişkin } \\
\text { beklenti, değer vb gibi konularda araştırmalarını } \\
\text { yapmalı ve bilimsel literatürü bu anlamda izleyerek } \\
\text { bilgi sahibi olmalıdır. }\end{array}$ & $\begin{array}{l}\text { Turizm işletmelerinde bebek patlaması } \\
\text { kuşağ1, X kuşağ1, Y ve Z kuşağ1 gibi } \\
\text { kuşaklara ait insanları çalıştı̆̆1 ve bu kuşaklar } \\
\text { arasında büyüdükleri döneme ait sosyal, } \\
\text { teknolojik, kültürel ve eğitim kaynaklı pek } \\
\text { çok farklılıkların oluştuğu, farklı değer } \\
\text { yarg1larına, alg1 ve beklentilere sahip oldukları } \\
\text { unutulmamalıdır. Bu farklılıklar dikkate } \\
\text { alınarak bu çalışanların beceri, memnuniyet } \\
\text { ve motivasyon kaynakları öğrenilmeli ve bu } \\
\text { doğrultuda fanlama } \\
\text { gerçekleştirilmelidir. }\end{array}$ \\
\hline $\begin{array}{l}\text { Çalışanlar arasındaki } \\
\text { kültürel farklılıkların } \\
\text { göz ardı edilmesi }\end{array}$ & $\begin{array}{l}\text { Turizm işletmeleri hizmet verdikleri alan itibariyle çok } \\
\text { farklı ulusal, etnik ve kültürel kimliğe sahip insanlara } \\
\text { hizmet vermektedir. Bu yüzden işletmelerin bazıları } \\
\text { ortaya çıkabilecek dil sorunlarını, gelen misafirlerin } \\
\text { güven sorunlarını aşabilmek ve kendilerini daha rahat } \\
\text { hissetmelerini sağlayabilmek için ağılıklı olarak } \\
\text { çalıştıkları bu pazarlara ait uluslardan çalışanları } \\
\text { bünyelerinde barındırabilmektedir. Örneğin Büyük bir } \\
\text { karşılayıcı acente hizmet verdiği tur operatörünün } \\
\text { bünyesinde faaliyet gösteren farklı ülkelere ait tur } \\
\text { operatörlerinin her birinden sezon içerisinde, tur } \\
\text { operatörü tarafından gönderilmiş, havaalanı karşılama } \\
\text { elemanı, transfer rehberi, otel rehberi ve sorumlu } \\
\text { rehber gibi çalışanları bünyesinde çalıştırmaktadır. } \\
\text { Aslında tur operatörünün personeli olan bu kişiler } \\
\text { sezon boyunca karşılayıcı acente yönetimi altında ve } \\
\text { onun kuralları doğrultusunda işlerini yürütmekte } \\
\text { ancak maaş ve sosyal güvence gibi hususlar tur } \\
\text { operatörü tarafından sağlanmaktadır. Bu durum hem } \\
\text { bu farklı ülkelerden gelen çalışanların kendi aralarında } \\
\text { hem de karşılayıc1 acentenin kendi çalışanları } \\
\text { arasındaki farklılıklardan doğan iş yapış yöntemleri, } \\
\text { işyerinden beklentileri vb. konularda sorunlara yol } \\
\text { açmaktadır. Ayrıca kendi ülkesinde farklı bir işletme } \\
\text { kültürü içinden gelen bu insanların geldikleri yeni } \\
\text { işletmedeki kültüre adaptasyon sorunları } \\
\text { oluşmaktadır. İnsan kaynakları birimi bu tür } \\
\text { sorunların asgari düzeye indirilmesi konusunda en } \\
\text { önemli role sahiptir. Benzer durum otel işletmeleri } \\
\text { içinde geçerli olup daha çok, bünyelerinde farklı } \\
\text { kültürlere ait insanların çalıştığ1 otellerin bu durumu } \\
\text { planlama sürecinde göz ardı etmesi sonucu ortaya } \\
\text { çıkmaktadır. }\end{array}$ & $\begin{array}{l}\text { İnsan kaynakları yöneticileri bu sorunu } \\
\text { engellemek ya da en düşük seviyede } \\
\text { tutabilmek için çeşitli yöntemler kullanabilir. } \\
\text { Bunlardan biri işletmelerin çalıştıkları her bir } \\
\text { tur operatörüyle düşük sezonlarda da } \\
\text { personel değişimi gerçekleştirerek işlerin çok } \\
\text { az olduğu dönemde kültürel oryantasyon ve } \\
\text { işletmelerin kendi kültürlerinin çalışanlarca } \\
\text { tanınması ve uyum sağlama süreçlerinin } \\
\text { atlatılması sağlanabilir. Bunu sağlamak içinde } \\
\text { her iki tarafın insan kaynakları yöneticilerinin } \\
\text { ortak çalışmalar gerçekleştirmeleri ve etkili } \\
\text { bir iletişim ağı oluşturmaları ile mümkündür. } \\
\text { Bir başka yöntem ise yine ölü sezonlarda } \\
\text { ortak eğitim programları ve iş başı eğitim } \\
\text { uygulamalarının yapılması olabilir. Ayrıca } \\
\text { tüm işletmelerin insan kaynakları birimleri } \\
\text { aracıllğılyla evrensel etik değerler, turizm etik } \\
\text { ilkeleri ve işletmenin etik kuralları konusunda } \\
\text { bilgi vermeleri ve bu etik çerçevenin işletme } \\
\text { içinde yöneticiler ve liderler aracılığıyla } \\
\text { pekiştirilmesini sağlayacak çalışmaların } \\
\text { yapılması gereklidir. }\end{array}$ \\
\hline
\end{tabular}

Kaynak: Jackson ve Schuler, 1990; Gomez-Meija vd. 2011; Majumder, 2014; Chand, 2015; Bingöl, 2016; Bianca, 2017; Rajshekar, 2017; Dillon, n.d den yararlanarak yazarlar tarafindan oluşturulmuştur.

Yukarıda bahsedilen sorunlar ișletmelerin yapılarına, yönetim felsefelerine, büyüklüklerine, faaliyet alanlarına ve sürelerine göre değişiklik gösterebilir. Örneğin sezonluk otel işletmesi ile tüm yıl faaliyet gösteren otel arasında işgören devir hızı farklı olacağından (Tuncer, 2014), bu işletmelerin bu sorunu yaşama düzeyleri farklı olacak ve planlamalarını bu doğrultuda yapmaları gerekecektir. Yine aynı şekilde bahsedilen farkl11ıkları dikkate almadan en iyi uygulama olarak gördüğü uygulamaları yurtdışı turlar düzenleyen bir seyahat acentesinden, bir karşılayıcı acentenin aynen alıp uygulaması işletmeye hiçbir yarar sağlamayacağı gibi zararlara neden olacaktır. Çünkü personel niteliklerinden iş tanımlarına, performans değerlendirme ve eğitim uygulamalarına kadar pek çok şey birbirinden farklıdır. Dolayısı ile insan kaynakları planlanırken her işletmenin kendine özgü bir planlama yapması ve bu planlamaların tüm işletmeyi kapsayacak şekilde olması önemlidir.

İnsan kaynakları planlamasının başarılı olmasına engel olan sorunlar sadece bahsettiğimiz bu sorunlardan oluşmayabilir. Bunlar dışında turizm işletmelerinin faaliyette bulundukları destinasyonun kültürel ve sosyal yapısı, işletmelerin sahiplik durumları, insan kaynağı arz ve talep durumları, ülkedeki 
turizm eğitiminin durumu, yasal ve geleneksel yapı ve yönetim felsefelerinden kaynaklı farklı sorunlarla karşılaşılabileceği unutulmamalıdır. Ancak sorun her ne olursa olsun sorunu oluşturan sebeplerin belirlenerek soruna özgü problem çözme yaklaşımları uygulanarak bunların üstesinden gelinebilir. İnsan kaynakları planlaması, iş piyasasında değişikliklere ayak uydurmak için organizasyonel öğrenmeyi, planlamayı ve personel becerilerini geliştirmeyi içermelidir (Bianca, 2017). Bu açıdan insan kaynakları planlamasının doğru yapılması öncelikle işletmenin kendini doğru tanımlamasına, işletme çevresini doğru analiz etmesine, ilgili teknolojileri takip etmesine, örgütsel öğrenme ve çalş̧an psikolojilerine önem vermesine ve işletme içinde üst yönetim, hat yöneticileri ve insan kaynakları yönetici ve planlayıcıları arasındaki etkili iletişime bağlıdır. Planlama süreci başından itibaren her adımı geri bildirimler ve süreç içi denetimler ile kontrol edilerek sorunlar ortaya çıkmadan önlenmeye çalışılmalı ya da en kısa sürede müdahale edilebilir esnek bir yapıda olmalıdır.

\section{Sonuç ve Değerlendirme}

İnsan kaynakları planlaması temel olarak işletmenin hedeflerine ulaşabilmesi için ihtiyaç duyulan işgücü sayısı ve niteliğinin tahminlenmesine ilişkin bir süreci ifade eder ve bu sürece iş analizi süreçleri de dâhildir. Ancak iş analizleri, iş tanımları ve gereklerinin belirlenmesiyle planlamaya girdi sağlayan ve planlamanın ilk aşamasını oluşturan işlemlerdir. Daha sonra bu süreç, ihtiyaç duyulan iş gücü ihtiyacının tahminlenmesi, kaynakları ve temin yöntemleri gibi konular ele alınarak devam ettirilir. İnsan kaynakları planlaması günümüzde işletmelerin faaliyetlerini sürdürebilmeleri açısından önemli bir insan kaynakları fonksiyonudur. İşletme içinde ve dışında gelişen olaylar, değişen müşteri beklentileri, teknolojik değişimler ve piyasa koşulları gibi unsurlara uyum sağlamak işgücü nitelik ve niceliğinin doğru belirlenmesiyle mümkün olabilmektedir. Özellikle hizmet üreten işletmelerde bu durumda daha fazla önem kazanmaktadır. Çünkü turizm işletmeleri gibi hizmet işletmelerinde hizmeti alanla veren insandır ve aralarında yoğun bir ilişki mevcuttur (Pelit ve Türkmen, 2007). Turizm işletmeleri de faaliyet alanı fark etmeksizin bütün diğer işletmeler gibi küreselleşme, çeşitlenen tüketici ihtiyaçlarının temininde kalite-fiyat dengesi ve artan rekabet sorunlarıyla mücadele etmektedir ve bu mücadele de başarılı olmak için işgücünün önemini göz önünde bulundurarak planlamasına önem vermelidir.

İnsan kaynakları planlamasının amacı, doğru insanların doğru zamanda doğru işte olmasını sağlamak olduğundan, organizasyonun stratejik planlarıla bağlantılı ve uyumlu olması gerekmektedir. İşletmelerin büyük bir kısmı, iş planları ve insan kaynakları planlaması arasındaki iki yönlü bir bağlantıdan yararlanmaları gerektiğinin farkında olmakla birlikte çeşitli sebeplerle bu bağlantıyı doğru oluşturamamaktadır. Bu ilişkiyi engelleyen ya da doğru kurulamamasına sebep olan unsurlardan bir kısmı, üst yönetimden kaynaklanırken, bir kısmı da insan kaynakları planlarının doğru yapılamaması ve bu yüzden işletme stratejik planlarına entegre edilirken yanlıs verilerin hesaba katılması nedeniyle olmaktadır. Özellikle Türkiye'de turizm işletmelerinde karşılaşılan bu sorun son yıllarda nispeten azalmış olsa da hala büyük çapta bir entegrasyon sorunu olduğu görülmektedir. Bu yüzden işletme genel planları yapilırken bu planların insan kaynakları planları ile koordine bir şekilde yapılması ve insan kaynakları planlarının bu stratejik planları destekleyici özellikte olması gerekmektedir.

Turizm işletmeleri özelinde insan kaynakları planlamasına ilişkin sorunlar ele alınırken incelenen literatürde, sorunların pek çoğunun tüm işletmelerde benzer özellikler gösterdikleri görülmüştür. Bununla birlikte bazı sorunların turizm işletmelerinde daha fazla ve düzeyinin daha yüksek olduğu belirlenmiştir. Bunlar; stajyerler ile ilgili planlama sorunları, nesiller arası farklılıkların dikkate alınmamasından kaynaklı planlama sorunları, kültürel farklılıkları göz ardı edilmesinden kaynaklı planlama sorunları, sayıların niteliğin önüne geçmesinden kaynaklı planlama sorunları, geriye yönelik tam ve doğru personel kayıtlarına sahip olunmamasından kaynaklı planlama sorunları, issgören devir hızının yüksekliğinden kaynaklı planlama sorunları ve işin niteliği ve çalışan becerileri arasındaki uyumsuzluktan kaynaklı planlama sorunları olarak sıralanmaktadır. Çalışmada bu sorunlarla birlikte diğer sorunlarda ele alınmış ve her birine yönelik insan kaynaklarının rolü ve çözüm önerileri getirilmeye çalışılmıştır.

İnsan kaynakları planlamasındaki turizm işletmelerinin karşılaştığı sorunlarla ilgili elde edilen bulgular değerlendirildiğinde, turizm işletmelerinin emek yoğun yapıları gereği insan kaynakları birimlerinin ve bu birimlerin gerçekleştirecekleri planlamaların işletme verimliliği ile doğrudan ilişkili olduğu ortaya çıkmaktadır. İşletmelerde stratejik planlamalara insan kaynakları birimlerinin dâhil edilmesi ve insan kaynakları planlamalarının bu stratejileri desteklemesinin büyük bir öneme sahip olduğu görülmektedir. Bu yüzden işletme stratejik planlarını destekleyecek insan kaynakları planlamalarının olabildiğince hatasız olması gerekmektedir. İnsan kaynakları planlaması insan kaynakları faaliyetlerinin bütününü ilgilendiren bir 
süreç olması nedeniyle planlamanın çeşitli sorunlar nedeniyle hatalı yapılması bütün diğer işlevlerinde yerine getirilirken çeşitli sorunlarla karşılaşmasına ya da hatalı işlemler yapılmasına yol açacaktır.

Turizm işletmelerinde insan kaynakları planlamasına ilişkin literatürde çeşitli çalışmalar olmasına rağmen insan kaynakları planlamasında ortaya çıkan sorunlara ilişkin çalışmalar sadece genel çerçevede ele alınmış olup turizm işletmelerinde ağırlıklı olarak karşılaşılan sorunların ele alındığı çalışmalara rastlanılmamıştır. $\mathrm{Bu}$ yüzden turizm işletmeleri özelinde insan kaynakları planlamasında karşılaşılan sorunların belirlenmesi ve bu sorunlara çeşitli öneriler getirmesi açısından bu çalışmanın literatürdeki bu boşluğu doldurmaya katkı sağlayacağı düşünülmektedir. Bu çalışma literatür taraması şeklinde teorik bir inceleme olup araştırmacıların deneyimleri ile desteklenmiş ancak ele alınan sorunlar uygulamalı olarak test edilmemiştir. Fakat çalışmanın sınırllılklarından biri olan bu durum gelecek çalışmalar için bir uygulama firsatı olarak görülebilir. Bu açıdan çalışmada ele alınan sorunların bundan sonra bu alanda çalışma yapmayı planlayan araştırmacılara uygulamalı araştırmalar yapmaları önerilebilir.

Konunun turizm işletmeleri açısından önemi göz önüne alınarak bu konuda yapılacak çalışmalara destek vermeleri en azından uygulamalı araştırmalar için işletmelerini araştırmacılara açmaları hem Türkiye turizminin en önemli ayağını oluşturan bu işletmelerin gelişimi hem de genel olarak turizm sektörünün ilerlemesi açısından önemlidir. Ayrıca turizm işletmeleri yöneticilerinin insan kaynakları planlamalarına destek vermeleri ve insan kaynakları yöneticilerini stratejik işletme planlama süreçlerine dâhil etmeleri ayrıca planlamaya ilişkin çalışmada ele alınan sorunları göz önünde bulundurarak bu süreçleri işletmeleri önemli görülmektedir.

\section{Etik Beyan}

"Turizm İşletmelerinde İnsan Kaynakları Yönetimi İşlevi Olarak İnsan Kaynakları Planlaması ve Sorunlar Üzerine Bir Değerlendirme" başlıklı bu çalışmanın yazım sürecinde bilimsel, etik ve alıntı kurallarına uyulmuş; toplanan veriler üzerinde herhangi bir tahrifat yapılmamış ve bu çalş̧ma herhangi başka bir akademik yayın ortamına değerlendirme için gönderilmemiştir.

\section{Kaynakça}

Ağaoğlu, O. K. (1992). İsgücünün verimli kullanma tekniklerinin turizm sektörüne uygulanması. Ankara: MPM Yayınlar1.

Anca-Ioana, M. (2013). New approaches of the concepts of human resources, human resource management and strategic human resource management. Annals of Faculty of Economics, University of Oradea, Faculty of Economics, 1(1), $1520-1525$.

Angelo M. R., ve Vladimir N. A. (1998). An Introduction to Hospitality Today. Orlando: Educational Institue American Hotel ve Motel Assocation.

Anthony, W. P.; Perrewe, P. L. ve Kacmar, K. M. (1996). Strategic Human Resource Management, New York: Dryden Press.

Arslan, M. L. (2012). İnsan Kaynakları Gereksinime Süreç Yaklaşımı: Stratejik İnsan Kaynakları Planlaması. Öneri Dergisi, 10(37), 89-101.

Aydın, Ş. (2005). Konaklama İsletmelerinde Insan Kaynaklar Yönetimi: İlkeler ve Uygulamalar. Ankara: Nobel Yayın Dağıtım.

Barney, J. ve Wright, P. (1998) On Becoming a Strategic Partner: The Role of Human Resources in Gaining Competitive Advantage, Human Resource Management, 37(1), 31-46.

Barutçugil, İ. (2004). Stratejike Insan Kaynaklar Yönetimi. İstanbul: Kariyer Yayınları.

Becker, B. ve Huselid, M. (1998). High Performance Work Systems and Firm Performance: A Synthesis of Research and Managerial Implications. (Ed.) Ferris, G. R. Research in Personnel and Human Resource Management, Greenwich,: JAI Press, pp.53-101.

Bianca, A. (2017). Problems and Issues of Human Resource Planning. Bizfluent. https://bizfluent.com/info-7752522problems-issues-human-resource-planning.html Erişim Tarihi: 09.11.2018.

Bingöl, D. (2016). Insan Kaynaklar Yönetimi. (10. Bask1), İstanbul: Beta Basım Yayım.

Björkman, I. ve Xiucheng, F. (2002). Human Resource Management and The Performance Of Western Firms in China. The International Journal of Human Resource Management, 13(6), 853-864. https://doi.org/10.1080/09585190210134246

Boella, M. J ve Gos-Turner, S. (2013). Human Resource Management in The Hospitality Industry. (9th Ed.), Oxon: Routledge.

Briggs, S. ve Keogh, W. (1999). Integrating Human Resource Strategy and Strategic Planning to Achieve Business Excellence. Total Quality Mangement, 10 (4/5), 447-453. https://doi.org/10.1080/0954412997398

Calp, M. H. (2016). İşletmelerde Uygulanan İnsan Kaynakları Yönetiminde Veri Tabanı Kullanımının Önemi. Gazi Üniversitesi İktisadi ve İdari bilimler Fakültesi Dergisi, 18 (2), 539-557.

Cania, L. (2014). The Impact of Strategic Human Resource Management on Organizational Performance. Economia Seria Management, 17 (2), 373-383. 


\section{PELİT ve ÇETIN}

Turizm İşletmelerinde İnsan Kaynakları Yönetimi İşlevi Olarak İnsan Kaynakları Planlaması ve Sorunlar Üzerine Bir Değerlendirme

Cascio, W. F. ve Aguinis, H. (2014). Applied Pschology in Human Resource Management. Essex: Pearson.

Chand, S. (2015). Problems Faced in Human Resource Planning. http://www.yourarticlelibrary.com/humanresources/problems-faced-in-human-resource-planning/35239 Erişim Tarihi: 16.11.2018.

Çalışkan, E. N. (2010). The Impact of Strategic Human Resource Management on Organizational Performance. Journal of Naval Science and Engineering, 6(2), 100-116.

Dallı, Ö. (1998). Turižmde Insan Kaynaklar Planlama ve Gelistirilmesi. 1. Turizm Şurası 20-22 Ekim, Ankara.

DeCenzo, D.A. ve Robbins, S.P. (2010). Human Resource Management. (10th Ed.), Asia Print, New Jersey: John Wiley ve Sons.

Delery, J. E. ve Doty, D. H. (1996) Modes of Theorizing in Strategic Human Resource Management: Tests of Universalistic, Contingency, and Configurational Performance Predictions, Academy of Management Journal, 39(4), 802-835. https://doi.org/10.2307/256713

Della Corte, V., Sciarelli, M., Cascella, C. ve Del Gaudio, C. (2015). Customer Satisfaction in Tourist Destination: The Case of Tourism Offer in the City of Naples. Journal of Investment and Management. Special Issue: Attractiveness and Governance of Tourist Destinations. 4(1-1), 39-50. https://doi.org/10.11648/j.jim.s.2015040101.16

Demir, C. ve Güzel, B. (2005). Planlama. Turizm İsletmelerinde İnsan Kaynaklar Yönetimi: İlkeler ve Uygulamalar, (Ed.) Demir, C., Ankara: Nobel Yayın, ss. 53-80.

Demir, Y. ve Çavuş, M. F. (2010). İnsan Kaynakları Planlamasının Etkinliğinde İnsan Kaynakları Bilgi Sistemleri. Akademik Bakıs Dergisi, (20), 1-17.

Deniz, M. ve Ünal, A. (2007). İnsan Kaynakları Fonksiyonu Olarak Örgütsel Kariyer Yönetimi ve Bir Uygulama. eJournal of New World Sciences Academy, 2 (2), 101-119.

Dillon, S. (n.d.). Factors Affecting Human Resource Plans. Small Business - Chron.com. http://smallbusiness.chron.com/factors-affecting-human-resource-plans-61165.html. Erişim Tarihi: 18.12.2018

Dolgun, U. (2007). İnsan Kaynaklar Yönetimi. Bursa: Ekin Kitabevi.

Erdem, B. (2004). Otel İşletmelerinde İnsan Kaynakları Planlamasının Yeri ve Önemi. İş Güc İnsan Kaynaklar ve Endüstri İliskileri Dergisi, (6) 1, 35-54.

Erdem, B. ve Tokmak, C. (2015). Turizm İşletmelerinde İnsan Kaynakları Planlaması. Turižm Issletmelerinde İnsan Kaynaklar Yönetimi, (Ed.) Pelit, E., Ankara: Grafiker Yayınları, ss. 131-198.

Geylan, R. (1996). Personel Yönetimi. Eskişehir: Birlik Ofset.

Gomez-Meija, L. R., Balkin, D. B. ve Cardy, L. R. (2012). Managing Human Resources. New Jersey: Pearson.

Gunarathne, U. (2014). Relationship between Service Quality and Customer Satisfaction in Sri Lankan Hotel Industry. International Journal of Scientific and Research Publications, 4(11), 1-8.

Güler, U. (2017). Insan Kaynaklar Yönetimi. https://umutguler.wordpress.com/insan-kaynaklari-yonetimi/ Erişim Tarihi: 12.11.2018.

Günel, Ö. D. (2009). Turizm Sektöründe Mevsimsellik Sorunu ve Mevsimlik İstihdamm Sektör Calıșanlarmmn Örgütsel Baglilıklarna Etkisi: Konaklama Issletmeleri Calıșanlarna Yönelık Bir Araștırma. Doktora Tezi, Dokuz Eylül Üniversitesi Sosyal Bilimler Enstitüsü, İzmir.

İbicioğlu, H. (2006). İnsan Kaynaklar Yönetimi: Kobiler Üzerine Bir Araștırma. Isparta: Fakülte Kitabevi Yayınları.

Jackson, S.E. ve Schuler, R. S. (1990). Human Resource Planning Challenges for Industrial/Organizational Psychologists. American Psychologist, 45(2), 223-239. https://doi.org/10.1037/0003-066X.45.2.223

Kayınova, Z. (2014). Konaklama Issletmelerinde Verimlilik. Turizm Gaz̧etesi, http:/ / www.turizmgazetesi.com/Article.aspx?Id=73539, Erişim Tarihi: 23.09.2018.

Kaynak, T. (1990). Personel Planlaması. İstanbul: İ.Ü.İ.I.E. Yayını.

Keklik, B. (2007). Insan Kaynaklar Temininde kullanulan Tekniklerin Etkinliklerine İliskin Kobilerde bir arassturma ve Model Önerisi. Doktora Tezi, Süleyman Demirel Üniversitesi Sosyal Bilimler Enstitüsü İşletme Anabilim Dalı, Isparta.

Kozak, M.A. (2012). Otel İsletmelerinde Insan Kaynaklar Yönetimi ve Örnek Olaylar. Ankara: Detay Yayınevi.

Kumar, R., (2011). Human Resource Management Strategic Analysis Text and Cases. New Delhi: I K International Publishing House.

Lew, A. ve McKercher, B. (2006). Modeling Tourist Movements A Local Destination Analysis. Annals of Tourism Research, 33 (2), 403-423. https:/ / doi.org/10.1016/j.annals.2005.12.002

Majumder, S. (2014). Importance of Human Resource Planning in Organizational Success. http://hrcsuite.com/humanresource-planning/ Erişim Tarihi: 30.11.2018.

Martin, G., Farndale, E., Paauwe, J. ve Stiles, P.G. (2016). Corporate Governance and Strategic Human Resource Management: Four Archetypes and Proposals for a new Aproach to Corporate Sustainability. Europan Management Journal, (34), 22-35. https://doi.org/10.1016/j.emj.2016.01.002

Mathis, R. L. ve Jackson, J. H. (2008). Human Resource Management. (12th Edt.), Mason: Thomson

Muoki, T. K. (2011). Challenges Of Human Resource Planning At The Ministry Of Public Health and Sanitation. A Management Research Project Submitted In Partial Fulfillment of The Requirements for The Award of Degree of Masters of Business Administration, University Of Nairobi.

Örücü, E. (2002). Turizm İşletmelerinde Orta ve Üst Kademe Yöneticilerin İşgören Seçme ve Değerlendirme Sürecindeki Eğilimleri (Marmaris ve Çevresindeki Üç Yıldızlı İşletmeler Örneği). Dokuそ Ellül Üniversitesi İktisadi ve İdari Bilimler Fakültesi Dergisi, 17(2), 119-132. 
Özer, M. A. (2015). İşletmelerde Stratejinin Önemi Üzerine Değerlendirmeler. Uluslararası İktisadi ve İdari İncelemeler Dergisi, (14), 69-84.

Pelit, E. ve Güçer, E. (2006). Turizm Alanında Öğretmenlik Eğitimi Alan Öğrencilerin Turizm İşletmelerinde Yaptıkları Stajları Değerlendirmeleri Üzerine Bir Araştırma. Ticaret ve Turizm Dergisi, (1), 139-164.

Pelit, E. ve Türkmen, F. (2007). Turizm İșletmelerinin Hizmet İçi Eğitimlerine Yönelik Bir Araştırma (Otel İşletmeleri ve Seyahat Acenteleri karşılaştırması). Abant İzzet Baysal Üniversitesi Sosyal Bilimler Enstitüsü Dergisi, $1(14), 202-226$.

Pelit, E. (2015). Turizm İşletmelerinde İnsan Kaynakları Yönetiminin Önemi. Turizm Issletmelerinde Insan Kaynaklarn Yönetimi, (Ed.) Pelit, E., Ankara: Grafiker Yayınları, ss.61-127.

Pelit, E. ve Çetin, A. (2019). Turizm İşletmelerinde İnsan Kaynakları Yönetimi İşlevi Olarak Performans Değerlendirme ve Sorunlar: Kavramsal Bir Değerlendirme. İstanbul Aydin Üniversitesi Dergisi, 11 (2), 165-203. DOI NO: 10.17932/IAU.IAUD.m.13091352.2019.2/42.165-203

Pilbeam, S. ve Corbridge, M. (2010). People Resourcing and Talent Planning in HRM. (4th Edition), New Jersey: Pearson.

Rajshekar, V. (2017), 8 Main Problems Involved In The Process Of Human Resource Planning In HRM. http://www.shareyouressays.com/knowledge/8-main-problems-involved-in-the-process-of-human-resourceplanning-in-hrm/94411. Erişim Tarihi: 04.11.2018

Reilly, P. (1996). Human Resource Planning An Introduction. IES Report 312. Brighton: The Institute for Employment Studies.

Sabuncuoğlu, Z. (2000). Insan Kaynaklar Yönetimi. Bursa: Ezgi Kitabevi

Saruhan, Ş. C. ve Yıldız, M. L. (2012). Insan Kaynaklar Yönetimi Teori ve Uygulama. İstanbul: Beta Basım Yayım.

Sonne, A.M. (1999). Determinants Of Customer Satisfaction With Professional Services- A Study Of Consultant Services. Okonomisk Fiskeriforksning, 9 (2), 97-107.

Temizkan, R. (2016). İnsan Kaynakları Planlaması. (Ed.) Tuna M., Insan Kaynaklar Yönetimi, Ankara: Detay Yayıncılık.

Tonus, H. Z. (2013). İnsan Kaynakları Planlaması ve İş Analizi. İnsan Kaynaklar Yönetimi, (Ed.) Geylan, R. ve Tonus, H. Z. Eskișehir: Anadolu Üniversitesi Yayınları, ss.34-59.

Torrington, D., Hall, L. Taylor, S. ve Atkinson, C. (2017). Human Resource Mnagement. 10th Edition, Harlow: Pearson. Tortop, N., Aykaç, B. Yayman, H. ve Özer, M. A. (2010). Insan Kaynaklar Yönetimi. Ankara: Nobel Yayın.

Tuna, M. (2007). Personel Devir Oranı Analizi: Ankarada Yer Alan Yıldızlı Otel İşletmelerinde Bir Uygulama. Anatolia: Turizm Arastermalar Dergisi, 18(1), 45-52.

Tuncer, M. (2014). Otel Çalışanlarının İşten Ayrılma Eğilimi: Sayfiye ve Şehir Otellerinde Bir Uygulama. Atatürk Üniversitesi Sosyal Bilimler Enstitüsü Dergisi, 18(3), 419-430.

UNWTO (2018). Employment and Decent Work in Tourism ILO-UNWTO Joint Project. http://statistics.unwto.org/en/project/employment-and-decent-work-tourism-ilo-unwto-joint-project (Erişim Tarihi: 24.03.2018).

Ünlüönen, K. ve Şahin, S.Z. (2011). Turizmde İstihdam. Elektronik Sosyal Bilimler Dergisi, 10 (37), 1-25.

Ünsalan, E. ve Şimşeker, B. (2011). İsletme Yönetimi I-II. Ankara: Detay Yayıncılık.

Yilmaz, S. (2008). Insan Kaynaklar Yönetimi. İstanbul: Lisans Yayıncilık.

Yüksel, Ö. (2000). Insan Kaynaklar Yönetimi. Ankara: Gazi Kitabevi.

\section{EXTENDED ABSTRACT}

Because of the customer satisfaction and loyalty are directly related to employee performance in tourism establishments, human resource planning is vital for the efficiency of these enterprises Human resources planning, which forms the basis of human resources management, constitutes the beginning of an entire human resources management process. Therefore, the planning of the whole process will ensure a healthy process. This study was carried out for the purpose of human resources planning in tourism enterprises, the role of human resources units and issues in planning and solutions to these issues. Human resources planning is a process of gathering information, analyzing and evaluating, estimating the future and applying the results (Saruhan \& Y1ldiz, 2012, p. 251). Human resources planning activities, where each of these stages have various applications in itself, are indispensable for enterprises to prevent the wastage or scarcity of enterprises and to determine their needs (Reilly, 1996, p. 16-17).

Tourism enterprises are among the enterprises which are within the services sector and are the most important production factor of labor within the production system which is rapidly mechanized after the industrial revolution. The competition among the enterprises in the tourism sector is extremely high (Lew \& McKercher, 2006). Success in this competitive environment depends on creating customer satisfaction. Customer satisfaction is dependent on the service produced (Sonne, 1999), and the service is based on labor in tourism enterprises, for this reason, increasing the service quality and ensuring customer satisfaction is directly proportional with having a qualified human resource (Pelit \& Gucer, 2006, p. 159). Therefore, the smooth running of human resources planning in tourism enterprises is an important activity concerning the whole enterprise. 
Human Resources planning is the process of determining the human resource need and supply method of the enterprise in the long term (DeCenzo \& Robbins, 2010). In addition, determination of the current workforce level and determination of the need, as well as personnel utilization and labor force development operations are carried out within the scope of planning activities (Keklik, 2007, p. 20). For this reason, human resources planning plays a vital role in the establishment of business strategies. Human resources planning can be discussed at two levels. The first is the approach that addresses the current situation of the employees within the organization and the expected change in the future regarding the human resources planning in the organizational dimension. The second one is the macro approach that addresses human resource planning on a larger scale. In this approach, the labor force of a country is examined by considering quality and quantity (Kozak, 2012, p. 57). Another approach is; Strategic and operational approaches to human resource planning (Björkman \& Xiucheng, 2002). Strategic human resources planning aims to ensure that the personnel needs of the organization for a certain period are at the required quality level in order to achieve the determined goals (Arslan, 2012, p. 91). This process should be realized in a long-term perspective. All activities related to human resources management in the enterprise should be started and carried out depending on human resources planning. Modern human resources planning is not only associated with the number of staff. It is a concept related to the development of qualitative elements such as the knowledge, skills and quality of the business besides the numerical planning (Dolgun, 2007: 33) and the formation, change and continuation of the culture in the organization. Especially, considering the effect of employee performance on operational efficiency, it is very important to create and adopt a culture to ensure customer satisfaction in tourism enterprises.

In terms of tourism enterprises, human resources planning is the most important; In countries where tourism is very important for the economy of the country such as Turkey not only business continuity but also country development should be taken into consideration. This point of view makes the qualified labor force mandatory. Therefore, businesses should act with strategic planning, not with the logic of "somehow we find out staff when we needed".

In carrying out effective human resources planning, the business faces various issues and challenges. Some of the problems that tourism enterprises often encounter are as follows (Jackson \& Schuler, 1990; Gomez-Meija et al. 2011; Majumder, 2014; Chand, 2015; Bingol, 2016; Bianca, 2017; Rajshekar, 2017; Dillon, n.d); the risk of errors and misconducts in human resource planning, lack of support from senior management, opposition or skepticism among management members, lack of complete and accurate personnel records, lack of leaders or the belief that the leader will do all the work, the numbers to override the quality, time and costs, very rigid business plans, interns to be seen as one of the main labor resources, internship time to leave the job without leaving or dismissal, the job values between generations not taken into account in planning and cultural differences between employees to be ignored. But these mentioned problems may vary according to the structures of the enterprises, management philosophies, size, activity areas and durations.

Considering the findings of the problems faced by tourism enterprises in human resources planning, due to the labor intensive structures of tourism enterprises, it is revealed that human resources units and the planning of these units are directly related to the operational efficiency. It is seen that the inclusion of human resources units in the strategic planning and the human resources planning supports these strategies. 